NBER WORKING PAPER SERIES

\title{
WAGE EFFECTS OF UNIONIZATION AND OCCUPATIONAL LICENSING COVERAGE IN THE UNITED STATES
}

\author{
Maury Gittleman \\ Morris M. Kleiner \\ Working Paper 19061 \\ http://www.nber.org/papers/w19061
NATIONAL BUREAU OF ECONOMIC RESEARCH
1050 Massachusetts Avenue
Cambridge, MA 02138

May 2013

An earlier version of this paper was presented at the meetings of the Allied Social Science Associations in San Diego in January 2013. We are grateful to our discussant, Mindy Marks, for her insightful remarks. We also thank Tony Barkume and Hwikwon Ham for comments, Brooks Pierce for very helpful discussions, William Nissan for research assistance, and Steve McClaskie for answering questions about the NLSY79. We are appreciative of support from the Federal Reserve Bank of Minneapolis and the Upjohn Institute for Employment Research. The views expressed here are those of the authors and do not necessarily reflect the views or policies of the Bureau of Labor Statistics, any other agency of the U.S. Department of Labor, or the National Bureau of Economic Research.

NBER working papers are circulated for discussion and comment purposes. They have not been peerreviewed or been subject to the review by the NBER Board of Directors that accompanies official NBER publications.

(C) 2013 by Maury Gittleman and Morris M. Kleiner. All rights reserved. Short sections of text, not to exceed two paragraphs, may be quoted without explicit permission provided that full credit, including (C) notice, is given to the source. 
Wage Effects of Unionization and Occupational Licensing Coverage in the United States Maury Gittleman and Morris M. Kleiner

NBER Working Paper No. 19061

May 2013

JEL No. J18,J24,J44,J5,J51,J82,J88,K2,K31,L43,L5,L51,L98

\begin{abstract}
$\underline{\text { ABSTRACT }}$
Recent estimates in standard models of wage determination for both unionization and occupational licensing have shown wage effects that are similar across the two institutions. These cross-sectional estimates use specialized data sets, with small sample sizes, for the period 2006 through 2008. Our analysis examines the impact of unions and licensing coverage on wage determination using new data collected on licensing statutes that are then linked to longitudinal data from the National Longitudinal Survey of Youth (NLSY79) from 1979 to 2010. We develop several approaches, using both cross-sectional and longitudinal analyses, to measure the impact of these two labor market institutions on wage determination. Our estimates of the economic returns to union coverage are greater than those for licensing requirements.
\end{abstract}

\author{
Maury Gittleman \\ Bureau of Labor Statistics \\ 2 Massachusetts Avenue NE, Rm 4130 \\ Washington, DC 20212 \\ gittleman_m@bls.gov \\ Morris M. Kleiner \\ University of Minnesota \\ Humphrey School of Public Affairs \\ 260 Humphrey Center \\ 301 19th Street South \\ Minneapolis, MN 55455 \\ and NBER \\ kleiner@umn.edu
}




\section{Introduction}

During the past 50 years in the United States, union membership has been declining, but the number of individuals who work in licensed occupations has been increasing (Kleiner and Krueger 2010). Recent cross-sectional estimates in standard models of wage determination for both of these important labor market institutions across the same data sets have shown similar wage effects for the two, averaging about 15 percent (Kleiner and Krueger 2010 and Kleiner and Krueger 2013). These estimates use specialized data sets during the period 2006 through 2008. Given the small sample size and cross-sectional construction of the surveys used in these studies on the wage outcomes of unions and occupational licensing, more research is needed to more fully understand the specific outcomes of such regulations.

We examine the impact of unions and licensing coverage on wage determination using new data collected on licensing statutes that are then linked to longitudinal data from the National Longitudinal Survey of Youth (NLSY79) from 1979 to 2010. This approach provides a fuller examination of the role of each of these institutions in the labor market.

In our examination of these two labor market institutions, we first review past studies on the role of both unions and occupational licensing on wage determination. The literature on wage determination under unions is well-developed and includes several syntheses by researchers such as Freeman and Medoff (1984), Lewis (1986), and Hirsch (2004). In contrast, the analysis of the wage effects of occupational licensing generally consists of cross-sectional estimates with appropriate human capital covariates but with few panel or time series examinations of the issue. Exceptions to these approaches include panel estimates and longitudinal measures of regulation (Kleiner 2006 and Thornton and Timmons 2013). 
Next in the empirical section we present cross-sectional estimates using the NLSY79 as a baseline in order to compare our estimates with those in the literature. Third, we specify the longitudinal methods that we utilize in the NLSY79. Our approach uses switchers, or workers who move into and out of unionization and licensing coverage, as well as individuals who do not move between these categories. Fourth, we are able to estimate the influence of licensing by linking each individual in the NLSY to whether the state they were in at the time of the switch had a licensing law covering the relevant occupations. In the conclusions, we state the implications for current and future research on the role of labor market institutions on wage determination.

\section{Labor Market Research on Unions and Occupational Licensing}

\section{A. Unions}

Traditional economic theory has generally treated the actions of trade unions in the labor market as a variant of monopoly behavior in product markets (Cartter 1959). For example, at the time of contract negotiations, the trade union acts as a single voice representing its members. Consequently, the employer is faced with a "single seller" of labor. Subsequent analysis by Freeman and Medoff (1984) argues that unions have both a monopoly and voice effect. The monopoly effect is similar to what has been presented by Cartter who suggests that supply is reduced, but the voice effect provides benefits beyond just the financial ones. For example, these include grievance procedures and the ability to have seniority determine promotions and wages, rather than only the assignment by the employer.

Unions also can engage in concerted activities such as strikes or work to rule which can raise the cost to the firm of employing organized workers relative to nonunion ones. If the 
company or plant wants to avoid these concerted activities, they have to pay the higher wage and benefit package. Therefore, unions have the ability to reallocate the firm's resources away from shareholders or capital investment and toward workers. Recent estimates of these reallocations are the present value of $\$ 40,500$ per worker over the duration of the worker’s employment with the firm (Lee and Mas 2012). To the extent that there are economic rents within the firm due to patents, location advantages, or economies of scale, unions are able to reallocate part of those resources toward union members. In addition, unions are given legitimacy and certain levels of economic protection through federal and state legislation, such as the National Labor Relations Act (Kleiner and Weil 2012). Consequently, through their ability to monopolize labor at the firm level and public policy protections, unions should be able to drive up wages.

Evidence from firms that have experienced new organizing drives shows that initially unions have small effects on wage determination (Freeman and Kleiner 1990 and Lee and Mas 2012). However, unions appear to have larger influences over time (Lee and Mas 2012). Since unions reached their highest level of organization and influence during the 1950s, their ability to drive up wages could reflect the long duration of their existence within an establishment.

There is a large body of labor market literature that has documented the wage gains from unionization (Lewis 1986). One of the major efforts of the empirical work is to estimate the union/nonunion relative wage differential or the wage gap. The estimates have been broken down by age, sex, region, industry, and occupation. The methods used have varied from cross-sectional and time-series approaches to panel estimates using difference-in-difference modeling. Further methodological techniques have included the use of both selection correction approaches and ones with vast arrays of observable covariates. A significant part of the literature has also focused on the simple "threat" or "spillover" interpretation of the wage effects. The general 
macro union relative wage effect estimates range from 15 to 20 percent (Lewis 1986). Updates in the U.S. find these estimates are robust up to the early 2000s (Hirsch 2004).

\section{B. Occupational Licensing}

In contrast to unionization, the stated objective of which is to protect workers, the perceived goal of occupational licensing is to protect the public against incompetent, untrustworthy, or irresponsible practitioners. Occupational regulation in the United States generally takes three forms. The least restrictive form is registration, in which individuals file their names, addresses, and qualifications with a government agency before practicing their occupation. The registration process may include posting a bond or filing a fee. In contrast, certification permits any person to perform the relevant tasks, but the government—or sometimes a private, nonprofit agency_administers an examination and certifies those who have achieved the level of skill and knowledge for certification. For example, travel agents and car mechanics are generally certified but not licensed. The toughest form of regulation is licensure; this form of regulation is often referred to as "the right to practice.” Under licensure laws, working in an occupation for compensation without first meeting government standards is illegal. In 2003, the Council of State Governments estimated that more than 800 occupations were licensed in at least one state, and more than 1,100 occupations were licensed, certified, or registered (Council on Licensure, Enforcement, and Regulation [CLEAR] 2004). The vast majority of occupations are licensed in some states and not in others.

Figure 1 shows trends in the growth of unionization and occupational licensing from 1950 to 2008 (Kleiner and Krueger 2013). Licensing data for earlier periods are available only at the state/occupational level; the data gathered through the Gallup and Westat surveys for 2006 and 2008 are denoted with a dashed line in the figure and represent the attainment of an 
occupational license (see Kleiner and Krueger, 2010 and 2013). Despite possible problems in both data series, occupational licensing clearly is rising, and unionization is clearly declining. ${ }^{1}$ By 2008, approximately 29 percent of workers polled in the Westat survey said they were required to have a government-issued license to do their job, compared with about 12.4 percent who said they were union members in the Current Population Survey (CPS) for the same year. Since occupational licensing experienced its more rapid growth since the 1970s, its economic impact may not be as high as unionization which has had a longer period to use collective bargaining to enhance earnings.

A basic explanation of occupational licensing suggests that administrative procedures regulate the supply of labor in the market. The regulators screen entrants to the profession and bar those whose skills or character traits suggest a tendency toward low-quality output. The regulators further monitor incumbents and discipline those whose performance is below standards, with punishments that may include revocation of the license needed to practice. Assuming that entry and ongoing performance are controlled in these ways, we would expect the quality of service in the profession to be raised by occupational licensing, but supply and access to services to be diminished.

Additional costs could include imposition of fines and screening to prevent expelled practitioners from reentering the occupation or the requirement that incumbents put up capital that would be forfeited upon loss of the license or incompetent or unscrupulous behavior. Entry requirements limit supply and create monopoly rents within the licensed occupation. The threat

\footnotetext{
${ }^{1}$ Growth in employment in occupations requiring licensing can be decomposed into shares attributable to growth in employment in occupations requiring licensing and to occupations becoming newly licensed. Kleiner (2006) finds that, for the state of Minnesota between 1990 and 2000, three-quarters of the growth was due to the first factor. While the general tendency over time is for more occupations to require licenses in more states, it seems safe to say that the majority of growth in occupational licensing is coming from employment increases in occupations in which licenses were already required.
} 
of losing these monopoly rents could, in principle, give incentives to incumbents to meet high standards. The rents also could motivate potential entrants to invest in high levels of training in order to gain admittance. Demand for the services of licensed workers could increase due to higher perceived quality and lower risk, but demand might also decrease for some segments of the occupation if some consumers demand lower quality services that are precluded by the licensing procedures (Shapiro 1986). An outward shift in demand could accentuate the increase in the price of services resulting from diminished supply, and further boost provider incomes. These models of licensing assume that consumers can choose among three markets: a market for mature producers known to sell high-quality services, a market for mature producers known to produce low-quality services, and a market for young producers whose quality of service (low or high) is not known by the consumer at the time of purchase (Shapiro 1986). The result is that seekers of high-quality services gain by regulation and seekers of low-quality services are worse off because prices are higher and choices more limited.

The source of market influence for occupational licensing is that the members of the occupation can manipulate the pass rate to restrict entry and raise wages (Friedman 1962; Maurizi 1974; and Pagliero 2010). Across a large number of recent studies on occupational licensing, which are primarily cross-sectional in methodology, the main result is that occupational licensing attainment increases wages by approximately 15 percent (Bryson and Kleiner 2010). This result is remarkably similar to those found for unionization. Unfortunately, the ability to examine the influence of licensing on wage determination using panel data analysis has been limited (Kleiner 2006, 2013; and Thornton and Timmons 2013).

In comparing licensing to unionization, the expectation is that unionization would have a larger influence on wage determination than licensing because unions showed sizeable growth 
during the 1940s through the 1950s, well before much of the growth of occupational licensing, which occurred after the 1970s. Several studies on the impact of licensing over time show that its influence grows over time as the occupations and administrative agencies are able to increase requirements for entry and restrict the supply of new practitioners (Kleiner and Vorotnikov 2012; Thornton and Timmons, 2013). To the extent that duration of the labor market institution matters in wage determination, then, unions would be the dominant labor market institution. In the following segments of the paper we show how the estimated longitudinal approach to unions and licensing is a better method of evaluating the wage effects of these two labor market institutions.

\section{The Data}

Given our interest in applying longitudinal methods to the analysis of the impact of unionization and licensing on wages, the main dataset we use is the National Longitudinal Survey of Youth, 1979 (NLSY79). The NLSY79 is a nationally representative sample of young men and women who were between the ages of 14 and 22 at the time of their first interview in 1979. Individuals have been surveyed annually beginning in 1979 and biennially beginning with 1994. The latest data available are for 2010. The NLSY79 has been widely used in studies of the labor market, because of the wealth of information it collects in this area.

The NLSY79 collects wage information on up to five jobs in each wave of the survey. For the purposes of our analysis, however, we restrict attention to the current/most recent job, also known as the Current Population Survey (CPS) job, in part because other labor market variables that we need are more readily available for this job. For brevity, we will refer to this job as the current one. To be included in our samples, we generally require, for each year for the 
current job, that an individual must be working for pay, have a valid wage, and a valid occupation in the data. In addition, the individual must not be enrolled in school (as of May of the survey year) and must have valid information on the state of residence (which is needed to determine whether the occupation requires a license). ${ }^{2}$ Further, to limit the influence of wage outliers, we also require that the wage be higher than one-half the real value of the minimum wage as of January $1,1981^{3}$ (\$3.35 in 1981 dollars) and be lower than $\$ 75$ per hour (in 2010 dollars). ${ }^{4}$

The occupation coding that the NLSY79 uses has changed over time. From 1979 through 2000, it uses the U.S. Census Bureau’s 1970 occupation codes, while, from 2002 on, it uses the Census codes for 2000. Characteristics of the sample are summarized in Table 1.

Despite the breadth of the labor market data collected in the NLSY79, that survey, in common with other large-scale surveys, does not collect information on whether a license is required for the individual's job. Thus, it is necessary to impute that information, which we do by using information from state laws for each individual in the sample. CareerOneStop, which is sponsored by the Employment and Training Administration of the U.S. Department of Labor, maintains a Web site containing a listing of occupations requiring licenses by state (http://www.acinet.org/licensedoccupations/, accessed April 13, 2012). This information is gathered by each state’s Labor Market Information unit, under a grant from the U.S. Department

\footnotetext{
${ }^{2}$ Licensing information is not available for the District of Columbia, so all individuals with residence there are eliminated from the sample. As discussed below, our information is on licensing at the state level, so that we do not have information on requirements at the local or federal levels.

${ }^{3}$ The deflator we use is the consumer price index research series (CPI-U-RS) from the Bureau of Labor of Statistics. ${ }^{4}$ Our results are not sensitive to the imposition of the $\$ 75$ limit, which was decided upon because of the way wage data are collected and computed in the NLSY79. The NLSY79 computes hourly wage rates by collecting a rate of pay and a time unit for that rate of pay (for example, hourly, weekly, annually). There is no top coding, but if an individual's rate of pay exceeds a maximum, his/her hourly wage will be marked as missing. From 1979 to 1993, the maximum rate of pay for any time unit was $\$ 99,999.99$; it was raised by a factor of 10 in 1994 , and there were further upward adjustments thereafter. Thus, the lowest maximum rate of pay in real terms occurs in 1993. If individuals reporting annually are working 2,000 hours a year, then the lowest maximum is equivalent to somewhat less than \$75 per hour in 2010 dollars.
} 
of Labor. The website provides four pieces of information for each listing: occupation, license name, licensing agency, and state. A screenshot of a page of the Web site is shown in Appendix A.

The occupations are based on those in the Standard Occupational Classification (SOC) system manual, so that each one listed either corresponds to a six-digit SOC code or fits neatly into one. Given that the 2000 Census codes are SOC-based, it is straightforward to map the occupations requiring licenses in a given state to their corresponding 2000 Census codes. For those 2000 Census codes involving at least some licensing requirement, we wish to assess whether the state requires all those in a given 2000 Census code to hold a license or whether only some in that code are required to have a license. Such partial licensing can come about for two sets of reasons. First, the group for which a license is required may be a subset of the 2000 Census code. For example, some states require licenses of electricians who are contractors but not of other electricians. As another example, certain licenses may be required of certain food and beverage workers only if they are employed in the gaming industry. Second, even if the occupation in the statute is the same as that in the 2000 Census code, it may be the case that not everyone is required to have a license in that occupation. Common examples of this type are the engineering professions, in which licenses are required but not everyone has one. We have more information on the first type of partial licensing than on the second. At the end of our efforts, we have a dataset which classifies every possible state by 2000 Census occupation pair into one of three categories: (1) no licensing requirement; (2) a license is required for some of the jobholders in the occupation; and (3) a license is required of all occupational incumbents.

A similar but more error-prone procedure is used to categorize each state by 1970 Census occupation pair. As with the 2000 Census codes, the occupations requiring licenses in each state 
need to be matched to a 1970 Census code. In many cases, this process is straightforward because many of the licensed occupations that have their own codes in the 2000 classification system had them in the 1970 system as well, or fit neatly into 1970 categories. When this is not the case, however, we have to surmount the obstacle that the occupation classification system has undergone major changes over the last four decades, particularly between the 1970 and 1980 Censuses and the 1990 and the 2000 ones. As there is no crosswalk from 1970 to 2000 that we are aware of, for some occupations it was necessary to track back over the different classification schemes to arrive at the best match in $1970 .^{5}$

Once the categorization of the state by 1970 occupation pairs is complete, we are in possession of a current licensing scheme that works for two different occupation classification systems. What we really want, however, are licensing schemes for every survey year from 1979 to 2000 using 1970 codes and ones for 2002 to the present using 2000 codes. Put differently, we want to know the starting date for the licensing requirement for all the state by occupation pairs. ${ }^{6}$ Unfortunately, we know of no source for this information. Instead, we are forced to make different sets of assumptions about how the current licensing schemes that we do have may have evolved over time and examine how sensitive our results are to these sets of assumptions. As we indicate below, for one set of assumptions, we have been able to narrow the number of occupations with a licensing requirement start date that needs researching down to the hundreds

\footnotetext{
${ }^{5}$ Detailed crosswalks are available for the changes from 1970 to 1980 (U.S. Bureau of the Census, 1989) and 1990 to 2000 (Scopp 2003); the changes from 1980 to 1990 are quite minor, especially in comparison. The closest we have seen to a 1970-2000 concordance is the valiant effort of Meyer and Osborne (2005) to put the occupation codes for the 1960, 1970, 1980, 1990, and 2000 Censuses onto a single, consistent basis. While we find their work to be a useful check on ours, we cannot apply it directly for a few reasons. First, our purpose is somewhat different in that, from the occupation or license name, we often know that we are working with a subset of a 2000 code rather than having to take all occupations in a 2000 code and match it to a 1970 code or codes. Second, for many 2000 codes there is no 1970 match in the Meyer and Osborne (2005) work. Third, it made sense for Meyer and Osborne to aggregate occupations to get better matches over time, but, in general, it does not for us, because we don't want to combine occupations that may be treated differently as far as licensing requirements are concerned.

${ }^{6}$ Implicitly, this formulation assumes that no occupations became unlicensed during the period, an assumption, which while not literally true, is probably not far off the mark (Timmons and Thornton 2013).
} 
from the thousands and have been able to check state statutes to see when these occupations first became licensed.

Our first step in the general process of assigning start dates is to take all the occupations that have some sort of licensing requirement in the current data, under both the 1970 and 2000 codes, and place them into one of three categories based on our knowledge of their licensing history. Those occupations with such a lengthy history of licensing that widespread requirements were in place before the start of the NLSY79 we placed in an Always licensed group, or group I. Examples of the Always licensed group include hairdressers, physicians, and accountants. Those occupations with little or no history of licensing requirements we placed in a Rarely licensed category (group III), which includes roofers, cooks, and upholsterers. The remaining occupations we placed in a middle group, the Moderately licensed (group II), which includes such occupations as electricians, librarians, and massage therapists. ${ }^{7}$

We use three different assumptions in terms of the timing of the start dates for licensing requirements. In order to simplify, we assume, with the one exception we note below, that the start date for all occupations in a group either precedes or follows the start of the NLSY79 panel. For the Always group, the start date is prior to the beginning of the panel in all three scenarios. For the Moderately group, it is prior to the panel in the second and third scenarios, and for the Rarely group, it is prior to the panel only in the third.

We are also interested in testing the sensitivity of the results to the treatment of the state by occupation pairs in which some licensing is required, given that an individual may be in a portion of the occupation not covered by licensing requirements or may be in a covered portion but not actually have a license. We place such pairs either with the wholly licensed or with the unlicensed. While the three scenarios times the two ways of treating the partially licensed

\footnotetext{
${ }^{7}$ A complete list for each group is available upon request.
} 
potentially lead to six different sets of assumptions, when only the Always occupations have a start date prior to the beginning of the panel, we only consider the case in which the partially licensed are treated as wholly licensed. That is because there are few occupations in group I that are not universally licensed. In the case with only wholly licensed occupations, we have actual dates for the start of licensing requirements for the Moderately and Rarely occupations. Table 2 lays out the five different sets of assumptions we consider.

The licensing definition names on Table 2, which will be used later, in the text and on other tables, have two parts. The Roman numeral is the highest number of the occupation groups that are assumed to have starting dates prior to the NLSY79 panel. Whole indicates that only occupations for which a license is required of the entire occupation is included, while Partial suggests that those occupations for which a license is required for just a portion of the incumbents are included as well.

To be clear about the interpretation of Table 2, let's consider the line with the licensing definition name of III-Whole. The second column entry of No indicates that occupations are only considered to require licenses when they are needed for the entire occupation. All three occupation groups—Always, Moderately, and Rarely—are included, so normally this would mean that we are assuming that the state by occupation pairs in each of these groups had licensing requirements beginning before the start of the NLSY79 panel. That is the case for the Always group, but the asterisks on Moderately and Rarely indicate that we have researched the relevant state by occupation pairs and determined the actual start date for the licensing requirements.

In Table 1, we show the prevalence of licensing requirements in our samples under each of the five definitions. By far, the most inclusive definition is the III-Partial, at an average of 
about 31 percent over the period. Next comes II-Partial at 18 percent and then II-Whole at 13 percent. The two remaining definitions include less than 11 percent of the sample. By way of comparison, Kleiner and Krueger (2013) estimate that 29 percent of the U.S. workforce attained a governmental license in 2008, but their estimates include those licensed not only by the state, but also by the federal and local governments. Their state-licensed only value was about 23 percent in 2008.

\section{Empirical Methods}

We are interested in the influence of two labor market institutions on wages. At the center of the analysis is the question, what is the impact of occupational licensing requirements on wages? Similarly, we are also interested in measuring the wage effect of unions, the presence of which we will measure by whether an individual is covered by a collective bargaining agreement. $^{8}$ While it is easy enough to state what we wish to measure, getting unbiased estimates is difficult for the usual reason: Even after controlling for the standard human capital characteristics when running a wage regression, one might still suspect that those who enter licensed occupations or obtain union coverage might differ from those who do not in ways that are unobservable to an econometrician. As a result, the variables of interest may be correlated with the error term, which would render ordinary least squares biased.

To address our questions, we try a number of different approaches. Our multivariate analysis begins with cross-sectional regressions with fairly standard controls, an approach which allows us to compare our results to past research. In addition, in the case of unions, Freeman (1984) argues that such an approach is superior to fixed effects, at least when one uses the short

\footnotetext{
${ }^{8}$ It is possible to determine union membership only in selected years in the NLSY79, but union coverage is available in all years, except for 1994, when the union questions were not asked of everyone.
} 
(two-year panels) that are produced from matching Current Population Surveys from adjacent years, because of a greater robustness to measurement error.

Our second approach is to attempt to control for the unobserved heterogeneity that may be biasing the results by including proxies for ability. The indicators of ability we use are Armed Services Vocational Aptitude Battery (ASVAB) test scores, which have been standardized and adjusted for year and quarter of birth. These tests consist of 10 categories: paragraph comprehension, general science, arithmetic reasoning, mathematics knowledge, word knowledge, mechanical comprehension, numerical operations, electronic information, auto and shop information, and coding speed.

Our third and fourth methods take advantage of the longitudinal structure of the NLSY79. We employ a nonparametric approach that classifies individuals on the basis of their licensing and union statuses in adjacent waves of the survey. Wage growth is then compared across the different categories, yielding the estimates of interest. For instance, in the simplest case, we compare the wage growth of those whose licensing status did not change to those who moved into a job requiring a license and those who moved out of such a job.

Finally, in our last approach, we use a more formal longitudinal method and estimate fixed-effects regressions. If one assumes that there is a fixed effect for each individual that is independent of sector and that is the source of the correlation between the sector status variables and the error term, then fixed effects will provide unbiased estimates.

In the analysis, we focus on one of the licensing definition variables, III-Whole, which is the one that includes our research on licensing requirement start dates for state by occupation pairs in the Moderately and Rarely categories. Besides the greater accuracy that comes from this research, we also gain an important source of variation, since we can observe occupations before 
and after they were licensed in a given state. As one of our robustness checks, however, we will also present results for the other licensing variables.

In addition, we know that all the licensing definition variables are affected by measurement error, an issue that is of particular importance when we do fixed-effects estimation. To address the measurement error issue directly, we will use techniques developed by Bollinger (1996, 2001) to bound the licensing parameters.

\section{Results}

Before turning to the multivariate analysis, it is of interest to examine briefly how those who face licensing requirements differ from those who do not. In Table 3, we show for each definition of licensing and for both the entire sample and the full-time only sample, means for

certain key characteristics. Across all the definitions, those who face licensing requirements tend to have higher levels of schooling, to be somewhat older, to be somewhat less likely to be African-American, and to be more apt to work in the government. Except for the most inclusive definition, union coverage and percentage female are somewhat higher in the licensed sector. These estimates are similar though not identical to the basic data found in the Princeton Data Improvement Initiative (PDII) on occupational licensing (Kleiner and Krueger 2013).

\section{A. Cross-Sectional Estimates}

Table 4 presents cross-sectional estimates of the effects of licensing requirements and union coverage on the log of wages. We use the III-Whole licensing definition and begin with the entire sample results. In the first column of estimates, to get a sense of the upper bound on the impact of licensing using this variable, we show the results of using an indicator for a 
licensing requirement as the sole regressor. ${ }^{9}$ We get a coefficient of 0.281 log points, similar to the $0.297 \log$ points that Kleiner and Krueger (2013) estimate in a similar model for attaining a license. Second, we add what we will refer to as our standard set of regressors. These include demographic and human capital variables (indicators for female, Hispanic and AfricanAmerican, as well as controls for years of schooling, potential experience, and potential experience squared), indicators for union coverage, government employment, self-employment, part-time status, and sets of dummy variables for major industry, ${ }^{10}$ state of residence, and year. The coefficient is sharply reduced, falling to 0.123 log points, suggesting that a good portion of the higher pay for those licensed is coming from such individuals having higher levels of schooling and other characteristics that are rewarded in the labor market.

Our next specifications add occupation controls. Though their use has become more common in labor economics in recent years, we recognize that controversy remains. We use them to enable within-occupation comparisons of those with licenses to those without, with the level of occupation aggregation going from major to two-digit to detailed. ${ }^{11}$ The addition of major occupation dummies (third column) leads to a further significant reduction in the return to licensing in percentage terms, with the coefficient declining to 0.078 log points. Thus, it seems that licensed occupations belong disproportionately to major occupations that tend to be higher paying even in the absence of licensing requirements. There is still considerable heterogeneity within major occupations, so we could be comparing, say, licensed electricians to unlicensed plumbers. The replacement of controls for major occupations with those for two-digit occupations (fourth column) results has almost no impact, but when controls are added for

\footnotetext{
${ }^{9}$ As will be noted later, because of measurement error, this is not actually an upper bound.

${ }^{10}$ There are 20 categories for major industry under the 1970 codes and 13 under the 2000 codes.

${ }^{11}$ Under the 1970 codes, there are 12 categories for major occupations, 44 for two-digits, and 450 for detailed. Under the 2000 codes, there are 10 categories for major occupations, 22 for two-digits, and 454 for detailed.
} 
detailed occupations (fifth column), the coefficients move very close to zero and are not statistically significant.

Our primary information on licensing refers to state by detailed occupation, although our research of state legislation has added some variation by year for this licensing definition. Because we include state and detailed occupation effects, along with year dummies, for licensing to have a significant measured impact on log wages, it must be the case that, all else equal, those in detailed occupations in the licensed states must either be higher paid than those in the same occupations in the states not requiring licenses or be higher paid relative to those in the same occupation in the same state when it did not require a license. According to the results in this table, that is not the case for the entire sample.

There are, however, two reasons to regard the results for the detailed occupations with some caution. First, there are a large number of detailed occupations, which would exacerbate the bias toward zero that results from measurement error. We will return to the impact of measurement error in the next section. Second, there is a question of how one is identifying the coefficient on licensing when detailed occupational controls are included. It turns out that, under the present licensing definition, only about one-fifth to one-quarter of employment is in detailed occupations in which some individuals are licensed and some are not, with most employment in occupations in which no individuals are licensed and a small amount (about 1 percent) in occupations in which all individuals are licensed. Thus, the coefficient on licensing will be identified on a subset of occupations, though a subset that includes the majority of occupations requiring licensing.

What are the results for union coverage? The coefficient on that variable is always statistically significant and is $0.155 \log$ points for the second specification, $0.180 \log$ points with 
major occupation dummies, and around $0.19 \log$ points for the two remaining specifications. Thus, in contrast to the case for licensing, with unionization the results for occupation controls indicate a slight tendency for those covered by a collective-bargaining agreement to be in occupations that tend to be low paying.

Turning briefly to the results for the full-time only sample, ${ }^{12}$ we see a similar pattern for the licensing coefficients, although starting from a lower base. The coefficient when licensing is the sole regressor is 0.247 log points, which falls to 0.096 points with standard controls, 0.059 and 0.066 points with major and two-digit occupations, and very close to zero with detailed occupations. The union coefficients tend to be 0.01 log points lower than in the full sample results.

Our second cross-sectional approach to estimating the returns to licensing requirements involves the inclusion of the ASVAB test scores as proxies for ability in the second through fifth specifications noted above. These results are presented in the second panel of Table 4. It turns out that the inclusion of the ASVAB test scores has virtually no impact on the licensing coefficients. It is not the case that the ASVAB scores are uncorrelated with both wages and with membership in a licensed occupation. Rather, it seems that, conditional on the inclusion of the standard controls, there is little relationship between the ASVAB scores and the licensing indicators. Similarly, the results for union coverage with the proxies for ability included are little different from those without them.

\section{B. Longitudinal Estimates}

Nonparametric. We begin the longitudinal analysis with a simple, nonparametric comparison of the growth of average log wages by group, with the groups defined on the basis of how licensing and union status evolved over time. In the first panel of Table 5, we show the

\footnotetext{
12 The part-time indicator is not needed as a regressor in this sample.
} 
average growth of log wages in adjacent survey years for three groups: (1) those who move out of jobs requiring licenses; (2) those who move into jobs requiring licenses; and (3) those whose licensing status does not change, which combines those who remain in unlicensed jobs with those who remain in licensed jobs. One can estimate the return to licensing either by subtracting the growth of the average log wages of those in category (1) from that of those in category (3) or by subtracting the growth in average log wages in category (3) from that of those in category (2). If the return to licensing is stable over time, then the two estimates should be equal.

The point estimate derived from comparing those who move out of licensed occupations to all who do not move is zero. The point estimates derived from comparing those who move into licensed occupations to all stayers is $0.01 \log$ points and is not statistically significant. In other words, according to this approach, the return to licensing is estimated to be quite small or nonexistent.

The second panel repeats the analysis in terms of union coverage instead of licensing status. Both possible estimates of union coverage are $0.06 \log$ points and statistically significant, which is considerably lower than the estimates from the cross-sectional results, but consistent with other findings that show longitudinal results are smaller.

Finally, for the purposes of the third panel, we examine switches into and out of licensing and union coverage simultaneously. In any given year, an individual may be in one of four categories in terms of union coverage and license requirements. Given that, there are sixteen different possible patterns ( 4 by 4 ) for two adjacent years. Excluding those cases in which an individual switches into licensing and out of union coverage or vice versa, these categories can be summarized into the seven categories presented in the third panel. Making the appropriate subtractions yields estimates of returns to licensing and to union coverage or to the sum of the 
two. The only cases in which the wage changes are statistically different from those for the no switch group are those for switching into and out of a union job, in both cases with the licensing status unchanged. Both imply a return to unions of 0.06 log points, as in the second panel. The group in which individuals move into a job with union coverage and requiring a license tends to have fairly fast wage growth, but because that group tends to be a small one (for the number of observations, see Appendix B), the difference in wage growth for this group and that with no change in either status is not statistically significant.

Fixed Effects. We now turn to a formal longitudinal analysis using fixed effects, with results summarized in Table 6. We estimate a series of regressions, similar to those in our crosssectional analysis, except our standard set of regressors needs no longer to include variables that remain constant over time, namely, the indicators for female, Hispanic, and African-American. The first specification for the entire sample, the one with standard controls, suggests that those in licensed occupations earn 0.038 log points more than their unlicensed counterparts. Identification of this effect comes from the switches of individuals from an unlicensed job to a licensed one or vice versa. Through our sample criteria-in particular, the requirement that individuals cannot be enrolled in school—we have tried to avoid cases in which individuals are in one unlicensed occupation finishing training before switching to a different occupation that is licensed. In such a case, the individual might receive a wage increase, not as a result of licensing, but simply because the individual finished training or moved to a different occupation. As additional tests, we also try specifications in which we include occupation controls, ranging from major to detailed. Inclusion of major occupation controls nearly halves the coefficient to $0.020 \log$ points, a small reduction in an absolute sense. Moving to the next level of occupation 
detail actually increases the returns to licensing somewhat, to 0.026 points. Finally, when detailed controls are included, the coefficient is reduced to essentially zero.

As mentioned earlier, the attenuation bias of measurement error is more pronounced in the presence of fixed effects (Griliches and Hausman 1986). Thus, it will be of interest to see what the bounds are when one takes into account measurement error.

The results for union premiums in the fixed-effects models are quite different from those for licensing returns. Irrespective of which occupational controls are included, those with union coverage are estimated to have earnings exceeding those who do not by $0.12-0.13$ log points, all else equal. Thus, the results fall somewhere in between those from the nonparametric longitudinal approach and those from the cross-sectional approaches.

Turning to the results for the full-time only sample, the same general patterns are present, but the coefficients for licensing tend to be a bit lower, as are those for union coverage.

\section{Robustness Checks}

In this section, we engage in four exercises to check on the robustness of our results in the previous section. First, we rerun the results using our alternative definitions of licensing. Second, we bound the licensing parameters, taking into account measurement error. Third, we rerun the results using just the 2002-2008 period, when measurement error is apt to be less of an issue because we do not need to recode the statute date to 1970 codes. Finally, we broaden our search for the impact of licensing, by considering aspects of nonwage compensation.

\section{A. Alternative Definitions of Licensing}

We now see if the results are robust to our alternative definitions of licensing, both those for the cross-sectional ones of Table 4 and the longitudinal ones of Table 6 . Though the 
licensing definition used thus far, III-Whole, includes all three groups-Always, Moderately, and Rarely—it actually has the lowest incidence of employment in occupations requiring licenses (Table 1). This low incidence rate is primarily due to its exclusion of occupations in which only part of the occupation requires a license. ${ }^{13}$

How do the results for the other definitions compare to those for III-Whole? In the crosssectional results for the entire sample (Table 7), first, when it is the sole regressor, licensing has a coefficient ranging from 0.160 to 0.285 log points, with an almost perfect inverse relationship between the restrictiveness of the definition and the impact. Thus, the results we have seen already are near the upper edge of this range, something that will be the case for all specifications. Second, the coefficients are reduced by more than one half with the inclusion of the standard controls, with the returns to licensing now running from 0.069 to 0.126 log points. The addition of major occupation dummies leads to a further significant reduction in the return to licensing in percentage terms, with the coefficients now ranging from 0.022 to 0.089 log points. As already seen, the replacement of controls for major occupations with those for two-digit occupations does not have a substantial additional impact, but when controls are added for detailed occupations, the coefficients move very close to zero and are never statistically significant, just as was the case for III-Whole.

For union coverage, the results are quite robust across the different definitions of licensing. The coefficient on that variable is always statistically significant and is consistently $0.16 \log$ points for the second specification, 0.18 log points with major occupation dummies, and 0.19 points with two-digit and detailed occupation controls.

\footnotetext{
${ }^{13}$ The incidence rate of III-Whole is even lower than that for II-Whole because the latter actually includes the small set of Always occupations that are partially licensed, while the former does not.
} 
The results for the full-time only sample are similar to those for the entire sample. The coefficients for licensing tend to be 0.01-0.02 points lower, but the patterns as covariates are added tend to be virtually identical. The difference between the returns to union coverage in the two samples tends to be somewhat smaller, about 0.01 points.

With the fixed-effects approach (Table 8), the parameters tend to be fairly robust across different licensing definitions, with those for III-Whole occurring near the upper end of a narrow range. The first specification for the entire sample, the one with standard controls, suggests that those in licensed occupations earn 0.027-0.044 log points more than their unlicensed counterparts. Inclusion of major occupation controls tends to lower the return to licensing by about $0.01-0.02$ log points, a small reduction in an absolute sense, but more substantial in percentage terms. Moving to the next level of occupation detail tends to have less effect, but, if anything, the direction is toward increasing the returns to licensing. Finally, when detailed controls are included, the coefficients on licensing are sharply reduced. They are, however, statistically significant in two cases, though always below 0.02 log points. Union premiums tend to be quite robust to licensing definition.

Turning to the results for the full-time only sample, the same general patterns are present, but the coefficients for licensing tend to be a bit lower, as are those for union coverage.

\section{B. Bounding the Licensing Parameters}

Bollinger (1996, 2001) extends the work of Aigner (1973) and others to show how bounds can be placed on the parameters of binary regressors, such as the licensing variables, and how such bounds can be tightened when auxiliary information is available on misclassification rates. These bounds are estimated on the assumptions that only the variable of interest is mismeasured and measurement error is independent of the other regressors. While such 
conditions may not hold exactly_-for instance, there is likely measurement error in the union coverage variable as well—we think the bounds that can be calculated are still informative.

In general, there are two types of misclassification rates when dealing with binary variables. Let $p$ equal the probability of reporting the individual as licensed when that person is not and $q$ equal the probability of reporting the individual as not licensed when the person actually has a license. Bounds can be computed without knowledge of $p$ and $q$, but Bollinger also shows that information on these misclassification rates can enable a narrowing of the bounds.

The PDII 2008 was conducted by Westat, and analyzed by Kleiner and Krueger (2013), provides a source of such information. Individuals are first asked:

"Do you have a license or certification issued by a federal, state, or local government agency to do your job?”

To distinguish between those who have a license and those who have a certification, those who say "yes" are then asked:

"Would someone who does not have a license or certificate be legally allowed to do your job?”

Those who answer "no" to the second question after having said "yes” to the first question are coded as licensed, while the remaining individuals are not. One can then consider this variable as providing a true measure of licensing.

Using the occupation codes and states of residence in the Westat survey, we can then recode individuals as being licensed or not based on the five licensing definitions that we used for the NLSY79. For each of these definitions, one can calculate a $p$ and a $q$. Using formulas from Bollinger (1996, 2001), one can then develop bounds for the licensing coefficients. The 
lower bounds are the actual coefficients, under the assumption that there is zero measurement error. The upper bounds assume that there is maximal measurement error, given the estimated $p$ and $q$.

For licensing definition III-Whole, the $p$, the estimated probability of incorrectly coding an individual as licensed is 0.034 . That is, our methodology codes as licensed only about 3 percent of those who are actually unlicensed. The other misclassification rate, $q$, at 0.170 , indicates that about one-sixth of those we code as licensed are not actually licensed. Using both these error rates, we calculate an upper bound for the licensing coefficient for each of the crosssectional models in Table 4 (excluding those with ASVAB scores as regressors) and fixedeffects models in Table 6, which we show in brackets on those same tables.

For all the models, the upper bound is roughly 50 percent higher than the lower bound estimated by the regression. Thus, despite the same relative impact, whether accounting for measurement error makes a substantial absolute difference depends on which model one believes to be most appropriate. If, for example, one views a cross-sectional model with one- or two-digit controls as most appropriate, then the upper bounds allow for returns to licensing as high as 0.12 log points for the full sample and from 0.09 to 0.10 log points for full-time only. For the crosssectional models with detailed occupational controls or for the fixed-effects models, the upper bound tends to be much lower (or even negative) because of the lower base.

\section{Limiting Samples to 2002-2008}

We are likely to have less measurement error in our licensing variable during the 20022008 period for two reasons. First, this span is more recent, so our current data are more likely to be applicable. Second, for this period we do not have to recode the occupations in our 
licensing data, since the NLSY79 and the statutory licensing data are both SOC-based during this period.

A comparison of the cross-sectional licensing coefficients in Table 9 for 2002-2008 with those in Table 4 for the entire period reveals that they are quite similar for the entire sample, and perhaps a little bit lower for the full-time only sample. There are, however, bigger differences in a comparison with the fixed-effects coefficients of Table 6. For the more recent period, the licensing coefficient is significant in one case, for the full-time sample when detailed occupational controls are used, and in this case the coefficient is negative $(-0.080)$. Thus, evidence from most recent period does not support the hypothesis that measurement error in 1979-2000 is lowering the return to licensing.

\section{Nonwage Compensation}

One possibility we have not considered thus far is that at least part of the payoff to licensing requirements comes in the form of nonwage compensation, something that has long been known to be the case for labor unions (e.g., Freeman and Medoff 1984; Lewis 1986). During each interview, the NLSY79 has usually collected information on access to the two most important fringe benefits: employer-provided health insurance and retirement plans. ${ }^{14}$ With our wage samples, we estimated linear probability models of access to these two benefits, using the same specification as in our other cross-sectional models. ${ }^{15}$

The results, shown in Table 10, confirm those of the earlier literature indicating that any estimates of the union wage gap are understatements of the union compensation gap. Those covered by a collective bargaining agreement are 12-13 percentage points more likely to have

\footnotetext{
${ }^{14}$ Information does not tend to be collected from some of the self-employed, those in unincorporated businesses. We tried the analysis two ways, including everyone but having a dummy variable for self-employed and excluding the self-employed and did not find the results to be sensitive.

${ }^{15}$ We estimated linear probability models rather than logits or probits for ease of convergence and for correcting for two-way clustering.
} 
access to employer-provided health insurance in the entire sample, 10-11 percentage points in the full-time sample. The union fringe benefit effect is even greater for retirement plans, with the difference being 17-19 percentage points and 16-17 percentage points, in the two samples.

The situation is quite different in the case of licensing. Without controls, those who are in occupations requiring licenses are about 6 percent more likely to have access to employerprovided health plans and about 10 percent more likely to have access to an employer-run retirement plan. The difference is completely erased, however, as soon as any controls are put into the regression.

\section{Discussion}

One overarching issue that separates the two institutions we have examined is the issue of coverage versus membership. For example, the effect of actually having a license may be much larger than that for just being in an occupation in which a license is required. This difference may be bigger than the effect for being covered by a collective bargaining agreement relative to that for being a union member. In Appendix C, we show the impact of membership versus coverage in the PDII for occupational licensing. The results show the difference is about 18 percent. Estimates for the difference between union membership and coverage are dramatically smaller, averaging about 6.7 percent (Blanchflower and Bryson 2004). Thus, part of the differences in the wage gaps for licensing and unionization that we find may be due to the larger premium for being a member of a licensed occupation relative to actual membership in comparison to these effects for unionization.

One other potential source of differences is that unionization's peak was in the 1950s and this institution has had a longer period during which to influence wages than occupational 
licensing which has seen its largest growth in the 1970s through 2010. Several studies have shown that occupational licensing takes longer to influence public policy and for lower quality members of the occupation who have not met current requirements to retire or leave the occupation and consequently influence labor supply (Kleiner and Vorotnikov 2012; Thornton and Timmons 2013). Consequently, the longer duration of unionization in the labor market may also be a source of the wage gap.

\section{Conclusions}

We have conducted a number of analyses, using both cross-sectional and longitudinal approaches, to measure the impact of two important labor market institutions, licensing and unionization, on wage determination in the United States. Using these different broad approaches, our estimates of the economic returns to union coverage are greater than those for licensing requirements.

We have performed a number of exercises to understand why the preponderance of our evidence suggests a generally small return to licensing requirements, when past research, though usually cross-sectional in nature, has tended to find a much larger one. Measurement error, while certainly an important issue, does not seem to fully explain it, and we have found no evidence of a return to licensing in the form of fringe benefits. Obtaining an occupational license, rather than being covered by a licensing law in an occupation, may matter more for wage determination than coverage in the unionized sector. Further research using the kind of analysis we have used here with longitudinal data and both membership and coverage will help labor economists and policymakers better understand the role of these two institutions on labor market outcomes. 


\section{References}

Aigner, Dennis J. 1973. "Regression with a Binary Independent Variable Subject to Errors of Observation.” Journal of Econometrics 1(1): 49-59.

Blanchflower, David G. and Alex Bryson. 2004. “The Union Wage Premium in the US and the UK.” CEP Discussion Paper 612, Centre for Economic Performance, London School of Economics and Political Science.

Bollinger, Christopher R. 1996. “Bounding Mean Regressions When a Binary Regressor Is Mismeasured.” Journal of Econometrics 73(2): 387-99. . 2001. “Response Error and the Union Wage Differential.” Southern Economic Journal 68(1): 60-76.

Bryson, Alex, and Morris M. Kleiner. 2010. “The Regulation of Occupations.” British Journal of Industrial Relations 48(4): 670-75.

Cameron, A. Colin, Jonah B. Gelbach, and Douglas L. Miller. 2011. “Robust Inference With Multiway Clustering.” Journal of Business \& Economic Statistics 29(2): 238-49.

Cartter, Allan M. 1959. Theory of Wages and Employment. Homewood, IL: R. D. Irwin.

Council on Licensure, Enforcement, and Regulation (CLEAR), 2004. http://www.clearhq.org/mission.

Freeman, Richard B. 1984. “Longitudinal Analyses of the Effects of Trade Unions.” Journal of Labor Economics 2(1):1-26.

Freeman, Richard B., and Morris M. Kleiner. 1990. “The Impact of New Unionization on Wages and Working Conditions.” Journal of Labor Economics 8(1, pt. 2): S8-25.

Freeman, Richard B., and James L. Medoff. 1984. What Do Unions Do? New York: Basic Books. 
Friedman, Milton 1962. Capitalism and Freedom. Chicago: University of Chicago Press.

Griliches, Zvi, and Jerry A. Hausman. 1986. “Errors in Variables in Panel Data.” Journal of Econometrics. 31(1): 93-118.

Hirsch, Barry T. 2004. "Reconsidering Union Wage Effects: Surveying New Evidence on an Old Topic.” Journal of Labor Research 25(2): 233-66.

Kleiner, Morris M. 2006. Licensing Occupations: Enhancing Quality or Restricting Competition? Kalamazoo, MI: Upjohn Institute for Employment Research. . 2013. Stages of Occupational Regulation, Kalamazoo, MI: Upjohn Institute for Employment Research.

Kleiner, Morris M., and Alan B. Krueger. 2010. “The Prevalence and Effects of Occupational Licensing.” British Journal of Industrial Relations 48(4): 676-87.

Kleiner, Morris M. and Alan B. Krueger. 2013. “Analyzing the Extent and Influence of Occupational Licensing on the Labor Market.” Journal of Labor Economics.Vol. 31, S1, April. Pp. S173-S202.

Kleiner, Morris M., and Evgeny Vorotnikov. 2012. “Complementarity and Substitution Between Licensed and Certified Occupations: An Analysis of Architects and Interior Designers.” Working Paper, University of Minnesota. Unpublished.

Kleiner, Morris M., and David Weil. 2012. "Evaluating the Effectiveness of National Labor Relations Act Remedies: Analysis and Comparison with Other Workplace Penalty Policies.” In Research Handbook on the Economics of Labor and Employment Law, ed. Cynthia L. Estlund and Michael L. Wachter, 209-47. Cheltenham, U.K.: Elgar. 
Lee, David S., and Mas, Alexandre. 2012. “Long-Run Impacts of Unions on Firms: New Evidence from Financial Markets, 1961-1999.” Quarterly Journal of Economics 127(1): 333-78.

Lewis, H. Gregg, 1986. “Union Relative Wage Effects.” In Handbook of Labor Economics, vol. 2, ed. Orley C. Ashenfelter and Richard Layard, 1139-81. Amsterdam: North-Holland. Maurizi, Alex R. 1974. “Occupational Licensing and the Public Interest.” Journal of Political Economy 82(2): 399-413.

Meyer, Peter B., and Anastasiya M. Osborne. 2005. “Proposed Category System for 1960-2000 Census Occupations.” Working Paper 383, U.S. Bureau of Labor Statistics.

Moulton, Brent R. 1990. “An Illustration of a Pitfall in Estimating the Effects of Aggregate Variables on Micro Units.” Review of Economics and Statistics 72(2): 334-38.

Pagliero, Mario. 2010. “Licensing Exam Difficulty and Entry Salaries in the US Market for Lawyers.” British Journal of Industrial Relations 48(4): 726-39.

Scopp, Thomas S. 2003. “The Relationship Between the 1990 Census and Census 2000 Industry and Occupation Classification Systems.” Technical Paper 65, U.S. Census Bureau.

Shapiro, Carl. 1986. “Investment, Moral Hazard and Occupational Licensing.” Review of Economic Studies 53(5): 843-62.

Timmons, Edward J., and Robert Thornton. 2013. “The De-Licensing of Occupations in the United States.” Paper presented at the Labor and Employment Relations Association Meetings, San Diego, CA. Lehigh University. Unpublished.

Timmons, Edward J., and Robert Thornton. 2013. “Licensing One of the World’s Oldest Professions: Massage.” Journal of Law and Economics Vol. 55 (4). 
U.S. Bureau of the Census. 1989. "The Relationship Between the 1970 and 1980 Industry and Occupation Classification Systems.” Technical Paper 59, U.S. Government Printing Office, Washington, DC. 


\section{Figure 1}

Comparisons in the Time-Trends of Two Labor Market Institutions:

Percent Licensed and Unionized*

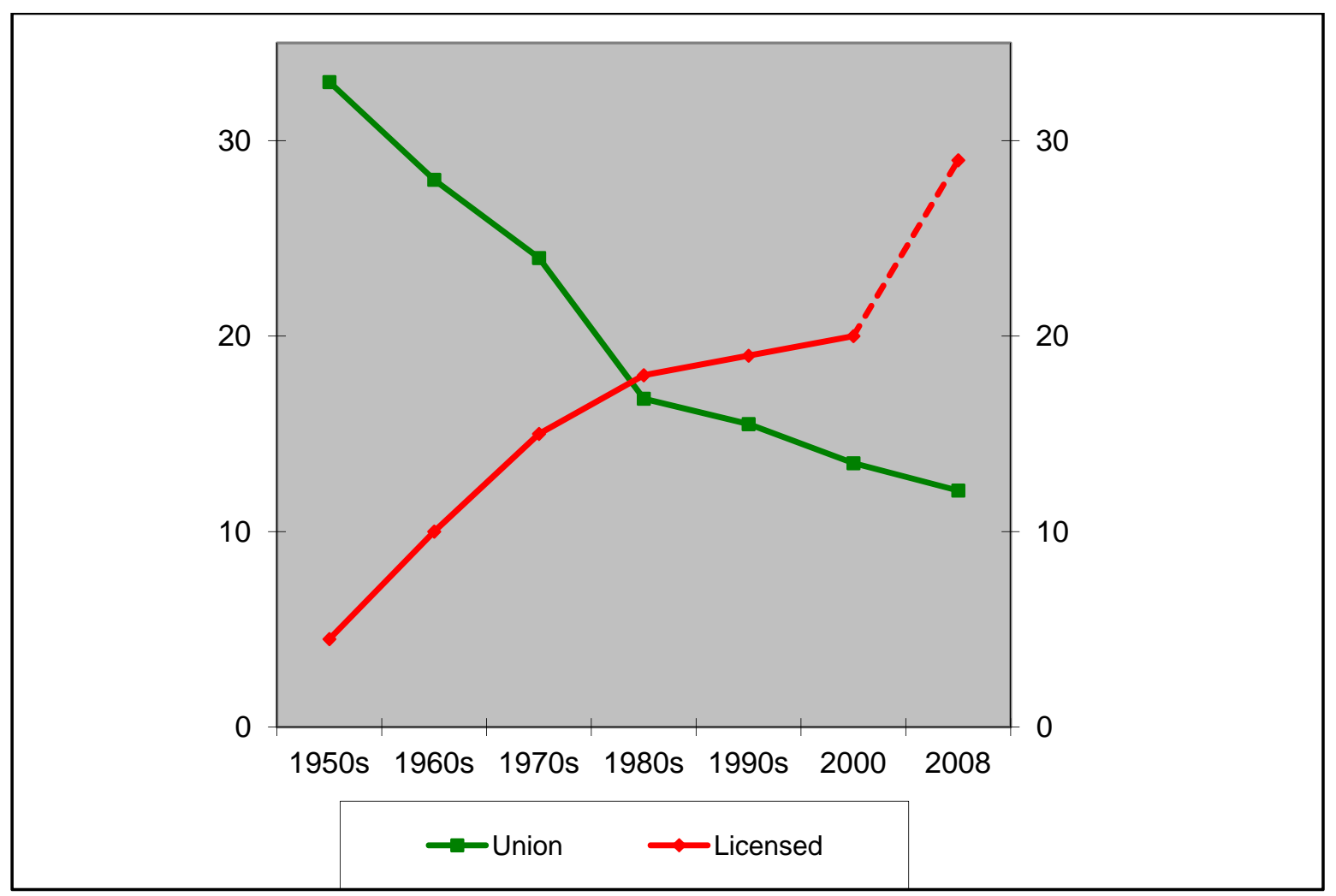

*Dashed line extends from State only estimates to the Gallup and Westat PDII estimates that includes licensing by all levels of government. Percent unionized are from the Current Population Report for various years 
Table 1

Characteristics of Samples

NLSY79, 1979-2008

\begin{tabular}{|c|c|c|c|c|}
\hline \multirow[b]{2}{*}{ Variable } & \multicolumn{2}{|c|}{ Entire Sample } & \multicolumn{2}{|c|}{ Full-Time Only } \\
\hline & Mean & Std. Dev. & Mean & Std. Dev. \\
\hline \multicolumn{5}{|l|}{ Licensing } \\
\hline \multicolumn{5}{|l|}{ Definitions: } \\
\hline III-Partial & 0.307 & 0.461 & 0.307 & 0.461 \\
\hline II-Partial & 0.180 & 0.384 & 0.181 & 0.385 \\
\hline II-Whole & 0.129 & 0.334 & 0.127 & 0.333 \\
\hline I-Partial & 0.109 & 0.312 & 0.106 & 0.308 \\
\hline III-Whole & 0.101 & 0.301 & 0.099 & 0.298 \\
\hline Union & 0.172 & 0.377 & 0.184 & 0.388 \\
\hline Age (yrs.) & 30.9 & 8.1 & 30.7 & 8.0 \\
\hline Female & 0.476 & 0.499 & 0.428 & 0.495 \\
\hline Hispanic & 0.062 & 0.240 & 0.063 & 0.243 \\
\hline African & 0.131 & 0.338 & 0.132 & 0.338 \\
\hline \multicolumn{5}{|l|}{ American } \\
\hline Schooling (yrs.) & 13.0 & 2.3 & 13.0 & 2.3 \\
\hline $\begin{array}{l}\text { Potential } \\
\text { experience (yrs.) }\end{array}$ & 11.9 & 8.0 & 11.7 & 7.9 \\
\hline Govt. & 0.113 & 0.317 & 0.117 & 0.322 \\
\hline Self-employed & 0.063 & 0.242 & 0.043 & 0.204 \\
\hline Part-time & 0.149 & 0.356 & 0 & 0 \\
\hline $\begin{array}{l}\text { Number of } \\
\text { observations }\end{array}$ & \multicolumn{2}{|c|}{136,368} & \multicolumn{2}{|c|}{112,273} \\
\hline
\end{tabular}

Notes: Unless otherwise indicated, variables are $0-1$, where 1 represents the presence of the characteristic. All labor market variables apply to current/most recent job. See text for licensing definitions. Union is an indicator variable for whether or not the job is covered by a collective bargaining agreement. Potential experience $=\max (0, \min ($ age-14, age-years of schooling-6)) . Part-time indicates usually worked fewer than 35 hours.

Includes all years of NLSY79 from 1979 to the present, except for 1994, when union questions were not asked of everyone in the sample, and 2010, when the variable indicating class of work was not available. To be included in the entire sample in any given year, individuals must (1) be working for pay and have a wage greater than $1 / 2$ the real value of the minimum wage as of January 1, 1981 (\$3.35 in 1981 dollars) and lower than $\$ 75$ per hour (in 2010 dollars); (2) not have been enrolled in school as of May of the survey year; (3) have valid state of residence data and be a resident of one of the 50 states; and (4) have valid occupation data. For the fulltime only sample, individuals must also be usually working 35 or more hours per week.

Weighted by NLSY longitudinal weights. 


\section{Table 2}

Licensing Definitions and Assumptions

\begin{tabular}{|l|c|l|}
\hline $\begin{array}{l}\text { Licensing } \\
\text { Definition Name }\end{array}$ & $\begin{array}{c}\text { Partially } \\
\text { Licensed } \\
\text { Included? }\end{array}$ & $\begin{array}{l}\text { Groups Whose Occupations Are Assumed to Have Been } \\
\text { Licensed Prior to Start of NLSY79 }\end{array}$ \\
\hline I-Partial & Yes & Always \\
\hline II-Whole & No $^{\text {a }}$ & Always and Moderately \\
\hline II-Partial & Yes & Always and Moderately \\
\hline III-Whole & No & Always, Moderately, and Rarely ${ }^{\text {b }}$ \\
\hline III-Partial & Yes & Always, Moderately, and Rarely \\
\hline
\end{tabular}

${ }^{\mathrm{a}}$ The small number of partially licensed occupations in the Always category are included.

${ }^{\mathrm{b}}$ Indicates actual licensing start date used instead of the assumption that licensing requirements for all occupations within groups in each state began before the start of the NLSY79. 
Table 3

Means of Characteristics of Samples By Licensing Status

All Definitions

\section{Entire Sample}

\begin{tabular}{|c|c|c|c|c|c|c|c|c|c|c|}
\hline Lic. Def. & \multicolumn{2}{|c|}{ III-Partial } & \multicolumn{2}{|c|}{ II-Partial } & \multicolumn{2}{|c|}{ II-Whole } & \multicolumn{2}{|c|}{ I-Partial } & \multicolumn{2}{|c|}{ III-Whole } \\
\hline & $=0$ & $=1$ & $=0$ & $=1$ & $=0$ & $=1$ & $=0$ & $=1$ & $=0$ & $=1$ \\
\hline Union & 0.177 & 0.160 & 0.167 & 0.191 & 0.168 & 0.195 & 0.170 & 0.188 & 0.169 & 0.196 \\
\hline Age (yrs.) & 30.7 & 31.4 & 30.6 & 32.3 & 30.7 & 32.4 & 30.7 & 32.5 & 30.7 & 32.7 \\
\hline Female & 0.477 & 0.475 & 0.468 & 0.512 & 0.467 & 0.541 & 0.463 & 0.585 & 0.464 & 0.589 \\
\hline Hispanic & 0.062 & 0.061 & 0.062 & 0.061 & 0.063 & 0.053 & 0.063 & 0.050 & 0.063 & 0.046 \\
\hline $\begin{array}{l}\text { African- } \\
\text { American }\end{array}$ & 0.144 & 0.103 & 0.137 & 0.107 & 0.135 & 0.108 & 0.135 & 0.102 & 0.134 & 0.102 \\
\hline $\begin{array}{l}\text { Schooling } \\
\text { (yrs.) }\end{array}$ & 12.7 & 13.6 & 12.8 & 14.1 & 12.8 & 14.4 & 12.8 & 14.7 & 12.8 & 14.8 \\
\hline $\begin{array}{l}\text { Potential } \\
\text { experience } \\
\text { (yrs.) }\end{array}$ & 11.9 & 11.7 & 11.8 & 12.2 & 11.9 & 12.0 & 11.9 & 11.8 & 11.9 & 12.0 \\
\hline Govt. & 0.103 & 0.135 & 0.096 & 0.192 & 0.098 & 0.219 & 0.100 & 0.225 & 0.101 & 0.229 \\
\hline $\begin{array}{l}\text { Self- } \\
\text { employed }\end{array}$ & 0.057 & 0.075 & 0.062 & 0.063 & 0.062 & 0.065 & 0.062 & 0.064 & 0.062 & 0.065 \\
\hline Part-time & 0.151 & 0.146 & 0.151 & 0.140 & 0.149 & 0.150 & 0.148 & 0.160 & 0.148 & 0.154 \\
\hline
\end{tabular}

Full-Time Only

\begin{tabular}{|l|cc|c|c|c|c|c|c|c|c|}
\hline Lic. Def. & \multicolumn{2}{|c|}{ III-Partial } & \multicolumn{2}{c|}{ II-Partial } & \multicolumn{2}{c|}{ II-Whole } & \multicolumn{2}{c|}{ I-Partial } & \multicolumn{2}{c|}{ III-Whole } \\
\hline & $=0$ & $=1$ & $=0$ & $=1$ & $=0$ & $=1$ & $=0$ & $=1$ & $=0$ & $=1$ \\
\hline Union & 0.191 & 0.170 & 0.180 & 0.204 & 0.181 & 0.209 & 0.182 & 0.200 & 0.182 & 0.208 \\
Age (yrs.) & 30.6 & 31.4 & 30.5 & 31.8 & 30.6 & 31.8 & 30.6 & 31.9 & 30.6 & 31.1 \\
Female & 0.430 & 0.422 & 0.422 & 0.456 & 0.419 & 0.485 & 0.416 & 0.531 & 0.416 & 0.533 \\
Hispanic & 0.063 & 0.064 & 0.062 & 0.064 & 0.064 & 0.056 & 0.064 & 0.053 & 0.065 & 0.048 \\
$\begin{array}{l}\text { African- } \\
\text { American }\end{array}$ & 0.144 & 0.104 & 0.136 & 0.111 & 0.134 & 0.115 & 0.135 & 0.108 & 0.135 & 0.107 \\
$\begin{array}{l}\text { Schooling } \\
\text { (yrs.) }\end{array}$ & 12.8 & 13.7 & 12.8 & 14.1 & 12.8 & 14.4 & 12.8 & 14.7 & 12.9 & 14.8 \\
$\begin{array}{l}\text { Potential } \\
\text { experience } \\
\text { (yrs.) }\end{array}$ & 11.8 & 11.4 & 11.7 & 11.7 & 11.7 & 11.4 & 11.8 & 11.1 & 11.7 & 11.3 \\
Govt. & 0.107 & 0.140 & 0.099 & 0.199 & 0.101 & 0.229 & 0.103 & 0.236 & 0.103 & 0.243 \\
$\begin{array}{l}\text { Self- } \\
\text { employed }\end{array}$ & 0.039 & 0.054 & 0.044 & 0.040 & 0.044 & 0.039 & 0.044 & 0.039 & 0.044 & 0.038 \\
\hline
\end{tabular}


Notes: Unless otherwise indicated, variables are $0-1$, where 1 represents the presence of the characteristic. See text for licensing definitions and notes from Table 1 for variable definitions and sample criteria.

Weighted by NLSY79 longitudinal weights. 
Table 4

Impact of Licensing and Union Coverage on Wages

Licensing Definition: III-Whole

Cross-Sectional Estimates

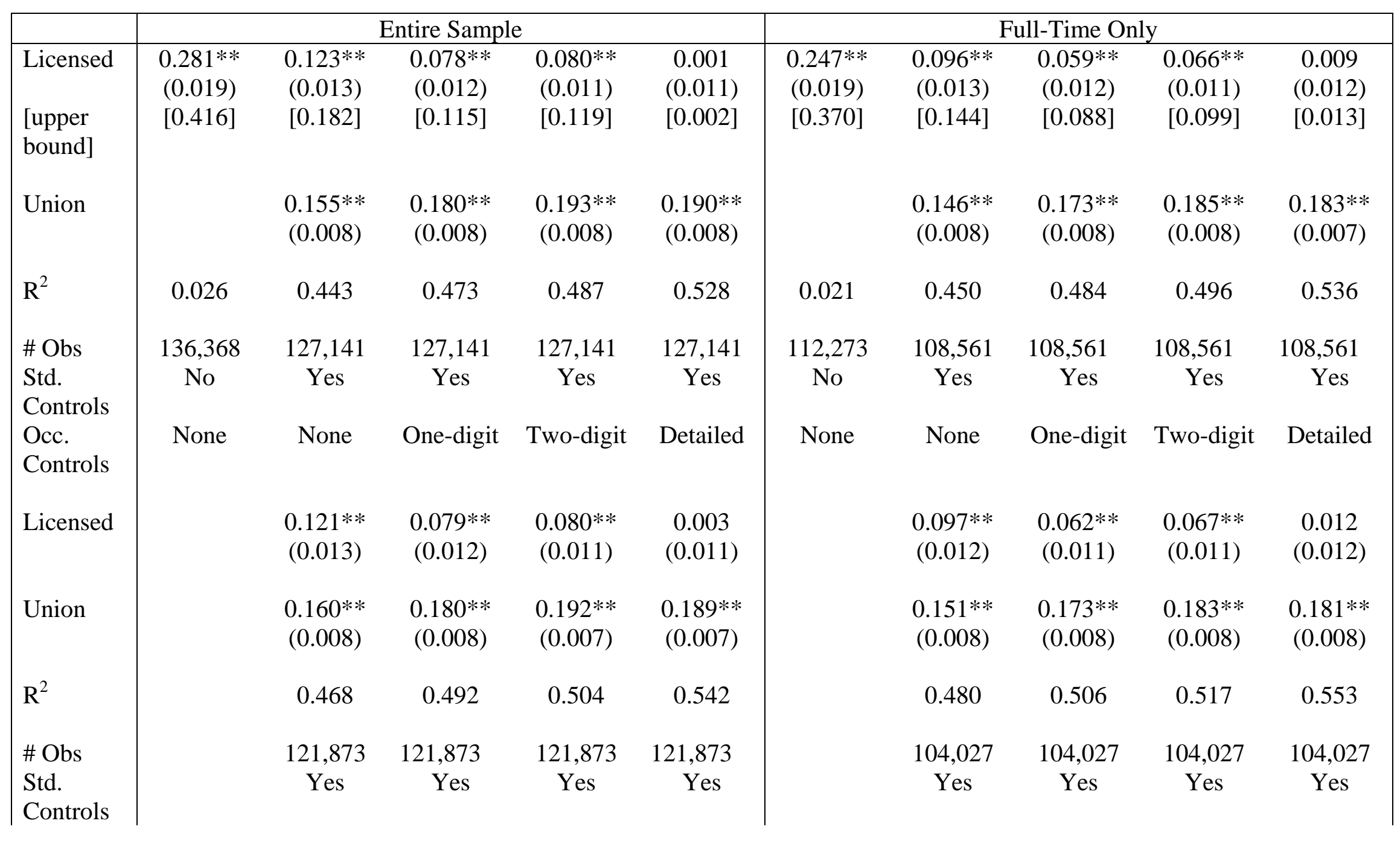




\begin{tabular}{|l|cccc|ccc} 
ASVAB & Yes & Yes & Yes & Yes & Yes & Yes & Yes \\
Controls & None & One-digit & Two-digit & Detailed & None & One-digit Two-digit Detailed \\
Occ. & & & & & &
\end{tabular}

Notes: See text for licensing definitions and notes from Table 1 for sample criteria. Standard controls include demographic and human capital variables (indicators for female, Hispanic and African-American, as well as controls for years of schooling, potential experience, and potential experience squared), indicators for union coverage, government employment, and self-employment, parttime status, and sets of dummy variables for major industry, state of residence, and year. There are 12 one-digit occupational categories under the 1970 codes and 10 under the 2000 codes, 44 two-digit categories under the 1970 codes and 22 under the 2000 codes, and 450 detailed categories under the 1970 codes and 454 under the 2000 codes.

Weighted by NLSY79 longitudinal weights.

Standard errors take account of complex survey design of NLSY79 and common group effects for detailed occupation by state cell (Moulton 1990; Cameron, Gelbach, and Miller 2011).

*Significant at 5 percent.

** Significant at 1 percent. 
Table 5

Changes in Log Wages Associated with Changes in Licensing Status and Union Coverage Licensing Definition: III-Whole

\begin{tabular}{|l|c|c|c|}
\hline & Out of Licensed Job & Into Licensed Job & No Changes \\
\hline Licensing Moves & 0.04 & 0.05 & 0.04 \\
\hline
\end{tabular}

\begin{tabular}{|l|c|c|c|}
\hline & Out of Union Job & Into Union Job & No Changes \\
\hline Union Moves & $-0.02^{* *}$ & $0.10^{* *}$ & 0.04 \\
\hline
\end{tabular}

\begin{tabular}{|l|l|l|l|l|l|l|l|}
\hline & Out of & Out of & Out of & Into & Into Union & Into & \\
& Licensed & Licensed & Union Job, & Licensed & Job, & Licensed & \\
and & Job, Union & Licensing & Job, Union & Licensing & and & \\
& Union & Status & Status & Status & Status & Union & No \\
& Job & Unchanged & Unchanged & Unchanged & Unchanged & Job & Changes \\
\hline Both & 0.01 & 0.04 & $-0.02^{* *}$ & 0.05 & $0.10^{* *}$ & 0.08 & 0.04 \\
\hline
\end{tabular}

Notes: *, ** indicate whether change is significantly different from group that makes no switch at 5 percent and 1 percent, respectively.

Each observation represents an individual's activity in a pair of adjacent survey years. Includes all adjacent pairs of years of NLSY from 1979-1980 to 2008-2010, except for those involving 1994, when union questions were not asked of everyone in the sample. To be included in the sample, individuals must, for both years in the pair, (1) be working for pay and have a wage greater than $1 / 2$ the real value of the minimum wage as of January 1, 1981 (\$3.35 in 1981 dollars) and lower than $\$ 75$ per hour (in 2010 dollars); (2) not have been enrolled in school as of May of the survey year; (3) have valid state of residence data and be a resident of one of the 50 states; (4) have valid occupation data; (5) have valid union coverage data; and (6) be usually working more than 35 hours per week.

Weighted by NLSY79 longitudinal weights.

Standard errors take account of complex survey design of NLSY79 and common group effects for detailed occupation by state cell (Moulton 1990; Cameron, Gelbach, and Miller 2011).

Number of observations: 81,168. For observations by cell, see Appendix B. 
Table 6

Impact of Licensing and Union Coverage on Wages

Fixed-Effects Estimates

Licensing Definition: III-Whole

\begin{tabular}{|c|c|c|c|c|c|c|c|c|}
\hline & \multicolumn{4}{|c|}{ Entire Sample } & \multicolumn{4}{|c|}{ Full-Time Only } \\
\hline $\begin{array}{l}\text { Licensed } \\
\text { [upper } \\
\text { bound] }^{\text {a }}\end{array}$ & $\begin{array}{c}0.038^{* *} \\
(0.008) \\
{[0.057]}\end{array}$ & $\begin{array}{c}0.020^{* *} \\
(0.008) \\
{[0.030]}\end{array}$ & $\begin{array}{c}0.026^{* *} \\
(0.008) \\
{[0.039]}\end{array}$ & $\begin{array}{c}-0.005 \\
(0.009) \\
{[-0.007]}\end{array}$ & $\begin{array}{c}0.017 * * \\
(0.007) \\
{[0.025]}\end{array}$ & $\begin{array}{c}0.005 \\
(0.007) \\
{[0.007]}\end{array}$ & $\begin{array}{c}0.009 \\
(0.007) \\
{[0.014]}\end{array}$ & $\begin{array}{c}-0.001 \\
(0.009) \\
{[-0.001]}\end{array}$ \\
\hline Union & $\begin{array}{c}0.124^{* *} \\
(0.005)\end{array}$ & $\begin{array}{c}0.127^{* *} \\
(0.006)\end{array}$ & $\begin{array}{c}0.131^{* *} \\
(0.006)\end{array}$ & $\begin{array}{c}0.128^{* *} \\
(0.006)\end{array}$ & $\begin{array}{c}0.113^{* *} \\
(0.006)\end{array}$ & $\begin{array}{c}0.116^{* *} \\
(0.007)\end{array}$ & $\begin{array}{c}0.119 * * \\
(0.006)\end{array}$ & $\begin{array}{c}0.116^{* *} \\
(0.006)\end{array}$ \\
\hline $\mathrm{R}^{2}$ & 0.328 & 0.338 & 0.345 & 0.374 & 0.372 & 0.381 & 0.386 & 0.412 \\
\hline \# Obs & 126,665 & 126,665 & 126,665 & 126,665 & 107,901 & 107,901 & 107,901 & 107,901 \\
\hline $\begin{array}{l}\text { Std. } \\
\text { Controls }\end{array}$ & Yes & Yes & Yes & Yes & Yes & Yes & Yes & Yes \\
\hline $\begin{array}{l}\text { Occ. } \\
\text { Controls }\end{array}$ & None & $\begin{array}{l}\text { One- } \\
\text { digit }\end{array}$ & $\begin{array}{l}\text { Two- } \\
\text { digit }\end{array}$ & Detailed & None & $\begin{array}{l}\text { One- } \\
\text { digit }\end{array}$ & $\begin{array}{l}\text { Two- } \\
\text { digit }\end{array}$ & Detailed \\
\hline
\end{tabular}

Notes: See text for licensing definitions and notes from Table 1 for sample criteria. Standard controls include human capital variables (controls for years of schooling, potential experience, and potential experience squared), indicators for union coverage, government employment, and self-employment, part-time status, and sets of dummy variables for major industry, state of residence, and year. There are 12 one-digit occupational categories under the 1970 codes and 10 under the 2000 codes, 44 two-digit categories under the 1970 codes and 22 under the 2000 codes, and 450 detailed categories under the 1970 codes and 454 under the 2000 codes.

Weighted by NLSY79 longitudinal weights.

Standard errors take account of complex survey design of NLSY79 and common group effects for detailed occupation by state cell (Moulton 1990; Cameron, Gelbach, and Miller 2011).

*Significant at 5 percent.

**Significant at 1 percent.

${ }^{a}$ When coefficient is negative, lower bound is given. 
Table 7

Impact of Licensing and Union Coverage on Wages

Cross-Sectional Estimates

Alternative Licensing Definitions

\begin{tabular}{|c|c|c|c|c|c|c|c|c|c|c|}
\hline \multirow{2}{*}{\begin{tabular}{|l|} 
\\
III- \\
Partial \\
Licensed
\end{tabular}} & \multicolumn{5}{|c|}{ Entire Sample } & \multicolumn{5}{|c|}{ Full-Time Only } \\
\hline & \multirow[t]{2}{*}{$\begin{array}{c}0.160 * * \\
(0.016)\end{array}$} & $\begin{array}{c}0.069 * * \\
(0.008)\end{array}$ & $\begin{array}{c}0.022 * * \\
(0.007)\end{array}$ & $\begin{array}{c}0.023 * * \\
(0.007)\end{array}$ & $\begin{array}{c}0.001 \\
(0.007)\end{array}$ & \multirow[t]{2}{*}{$\begin{array}{c}0.148 * * \\
(0.014)\end{array}$} & $\begin{array}{c}0.062 * * \\
(0.008)\end{array}$ & $\begin{array}{c}0.019 * * \\
(0.007)\end{array}$ & $\begin{array}{c}0.022 * * \\
(0.007)\end{array}$ & $\begin{array}{c}0.002 \\
(0.008)\end{array}$ \\
\hline Union & & $\begin{array}{c}0.157^{* *} \\
(0.008)\end{array}$ & $\begin{array}{c}0.181^{* *} \\
(0.008)\end{array}$ & $\begin{array}{c}0.194^{* *} \\
(0.008)\end{array}$ & $\begin{array}{c}0.190 * * \\
(0.008)\end{array}$ & & $\begin{array}{c}0.148 * * \\
(0.008)\end{array}$ & $\begin{array}{c}0.174^{* *} \\
(0.008)\end{array}$ & $\begin{array}{c}0.185 * * \\
(0.008)\end{array}$ & $\begin{array}{r}0.183 * * \\
(0.008)\end{array}$ \\
\hline $\mathrm{R}^{2}$ & 0.020 & 0.441 & 0.471 & 0.486 & 0.528 & 0.018 & 0.450 & 0.483 & 0.495 & 0.536 \\
\hline $\begin{array}{l}\text { II-Partial } \\
\text { Licensed }\end{array}$ & $\begin{array}{c}0.234^{* *} \\
(0.016)\end{array}$ & $\begin{array}{c}0.087 * * \\
(0.010)\end{array}$ & $\begin{array}{c}0.048 * * \\
(0.009)\end{array}$ & $\begin{array}{c}0.046^{* *} \\
(0.009)\end{array}$ & $\begin{array}{c}0.004 \\
(0.008)\end{array}$ & $\begin{array}{c}0.199 * * \\
(0.015)\end{array}$ & $\begin{array}{c}0.067^{* *} \\
(0.010)\end{array}$ & $\begin{array}{c}0.035 * * \\
(0.009)\end{array}$ & $\begin{array}{c}0.036 * * \\
(0.009)\end{array}$ & $\begin{array}{c}0.005 \\
(0.009)\end{array}$ \\
\hline Union & & $\begin{array}{c}0.155^{* *} \\
(0.008)\end{array}$ & $\begin{array}{c}0.180 * * \\
(0.008)\end{array}$ & $\begin{array}{c}0.193^{* *} \\
(0.007)\end{array}$ & $\begin{array}{c}0.190 * * \\
(0.007)\end{array}$ & & $\begin{array}{c}0.146^{* *} \\
(0.008)\end{array}$ & $\begin{array}{c}0.173 * * \\
(0.008)\end{array}$ & $\begin{array}{c}0.185^{* *} * \\
(0.008)\end{array}$ & $\begin{array}{c}0.183^{* *} \\
(0.008)\end{array}$ \\
\hline $\mathrm{R}^{2}$ & 0.029 & 0.442 & 0.472 & 0.486 & 0.528 & 0.023 & 0.450 & 0.483 & 0.496 & 0.536 \\
\hline $\begin{array}{l}\text { II-Whole } \\
\text { Licensed }\end{array}$ & $\begin{array}{c}0.256^{* *} \\
(0.018)\end{array}$ & $\begin{array}{c}0.101^{* *} \\
(0.013)\end{array}$ & $\begin{array}{c}0.068 * * \\
(0.011)\end{array}$ & $\begin{array}{c}0.075^{* *} \\
(0.010)\end{array}$ & $\begin{array}{c}0.004 \\
(0.011)\end{array}$ & $\begin{array}{c}0.219 * * \\
(0.017)\end{array}$ & $\begin{array}{c}0.076^{* *} \\
(0.012)\end{array}$ & $\begin{array}{c}0.051^{* *} \\
(0.010)\end{array}$ & $\begin{array}{c}0.060 * * \\
(0.010)\end{array}$ & $\begin{array}{c}0.009 \\
(0.011)\end{array}$ \\
\hline Union & & $\begin{array}{c}0.155^{* *} \\
(0.008)\end{array}$ & $\begin{array}{c}0.180^{* *} \\
(0.008)\end{array}$ & $\begin{array}{c}0.193 * * \\
(0.008)\end{array}$ & $\begin{array}{c}0.190 * * \\
(0.008)\end{array}$ & & $\begin{array}{c}0.146 * * \\
(0.008)\end{array}$ & $\begin{array}{c}0.173^{* *} \\
(0.008)\end{array}$ & $\begin{array}{c}0.185 * * \\
(0.008)\end{array}$ & $\begin{array}{r}0.183 * * \\
(0.008)\end{array}$ \\
\hline $\mathrm{R}^{2}$ & 0.027 & 0.442 & 0.473 & 0.487 & 0.528 & 0.021 & 0.450 & 0.484 & 0.496 & 0.536 \\
\hline
\end{tabular}




\begin{tabular}{|c|c|c|c|c|c|c|c|c|c|c|}
\hline $\begin{array}{l}\text { I-Partial } \\
\text { Licensed }\end{array}$ & $\begin{array}{c}0.285^{* *} \\
(0.019)\end{array}$ & $\begin{array}{c}0.126^{* *} \\
(0.014)\end{array}$ & $\begin{array}{c}0.089 * * \\
(0.012)\end{array}$ & $\begin{array}{l}0.089 * * \\
(0.011)\end{array}$ & $\begin{array}{c}0.008 \\
(0.013)\end{array}$ & $\begin{array}{l}0.248^{* *} \\
(0.019)\end{array}$ & $\begin{array}{c}0.099 * * \\
(0.014)\end{array}$ & $\begin{array}{c}0.068^{* *} \\
(0.011)\end{array}$ & $\begin{array}{c}0.082 * * \\
(0.011)\end{array}$ & $\begin{array}{c}0.016 \\
(0.013)\end{array}$ \\
\hline Union & & $\begin{array}{c}0.155^{* * *} \\
(0.008)\end{array}$ & $\begin{array}{c}0.180 * * \\
(0.008)\end{array}$ & $\begin{array}{l}0.193 * * \\
(0.008)\end{array}$ & $\begin{array}{c}0.190^{* *} \\
(0.008)\end{array}$ & & $\begin{array}{c}0.146^{* *} \\
(0.008)\end{array}$ & $\begin{array}{c}0.173^{* *} \\
(0.008)\end{array}$ & $\begin{array}{l}0.185^{* *} \\
(0.008)\end{array}$ & $\begin{array}{l}0.183^{* *} \\
(0.008)\end{array}$ \\
\hline $\mathrm{R}^{2}$ & 0.029 & 0.443 & 0.473 & 0.487 & 0.528 & 0.023 & 0.456 & 0.484 & 0.497 & 0.536 \\
\hline \# Obs & 136,368 & 127,141 & 127,141 & 127,141 & 127,141 & 112,273 & 108,561 & 108,561 & 108,561 & 108,561 \\
\hline $\begin{array}{l}\text { Std. } \\
\text { Controls }\end{array}$ & No & Yes & Yes & Yes & Yes & No & Yes & Yes & Yes & Yes \\
\hline $\begin{array}{l}\text { Occ. } \\
\text { Controls }\end{array}$ & None & None & One-digit & Two-digit & Detailed & None & None & One-digit & Two-digit & Detailed \\
\hline
\end{tabular}

Notes: See text for licensing definitions and notes from Table 1 for sample criteria. Standard controls include demographic and human capital variables (indicators for female, Hispanic and African-American, as well as controls for years of schooling, potential experience, and potential experience squared), indicators for union coverage, government employment, and self-employment, parttime status, and sets of dummy variables for major industry, state of residence, and year. There are 12 one-digit occupational categories under the 1970 codes and 10 under the 2000 codes, 44 two-digit categories under the 1970 codes and 22 under the 2000 codes, and 450 detailed categories under the 1970 codes and 454 under the 2000 codes.

Weighted by NLSY79 longitudinal weights.

Standard errors take account of complex survey design of NLSY79 and common group effects for detailed occupation by state cell (Moulton 1990; Cameron, Gelbach, and Miller 2011).

*Significant at 5 percent.

** Significant at 1 percent. 
Table 8

Impact of Licensing and Union Coverage on Wages

Fixed-Effects Estimates

Alternative Licensing Definitions

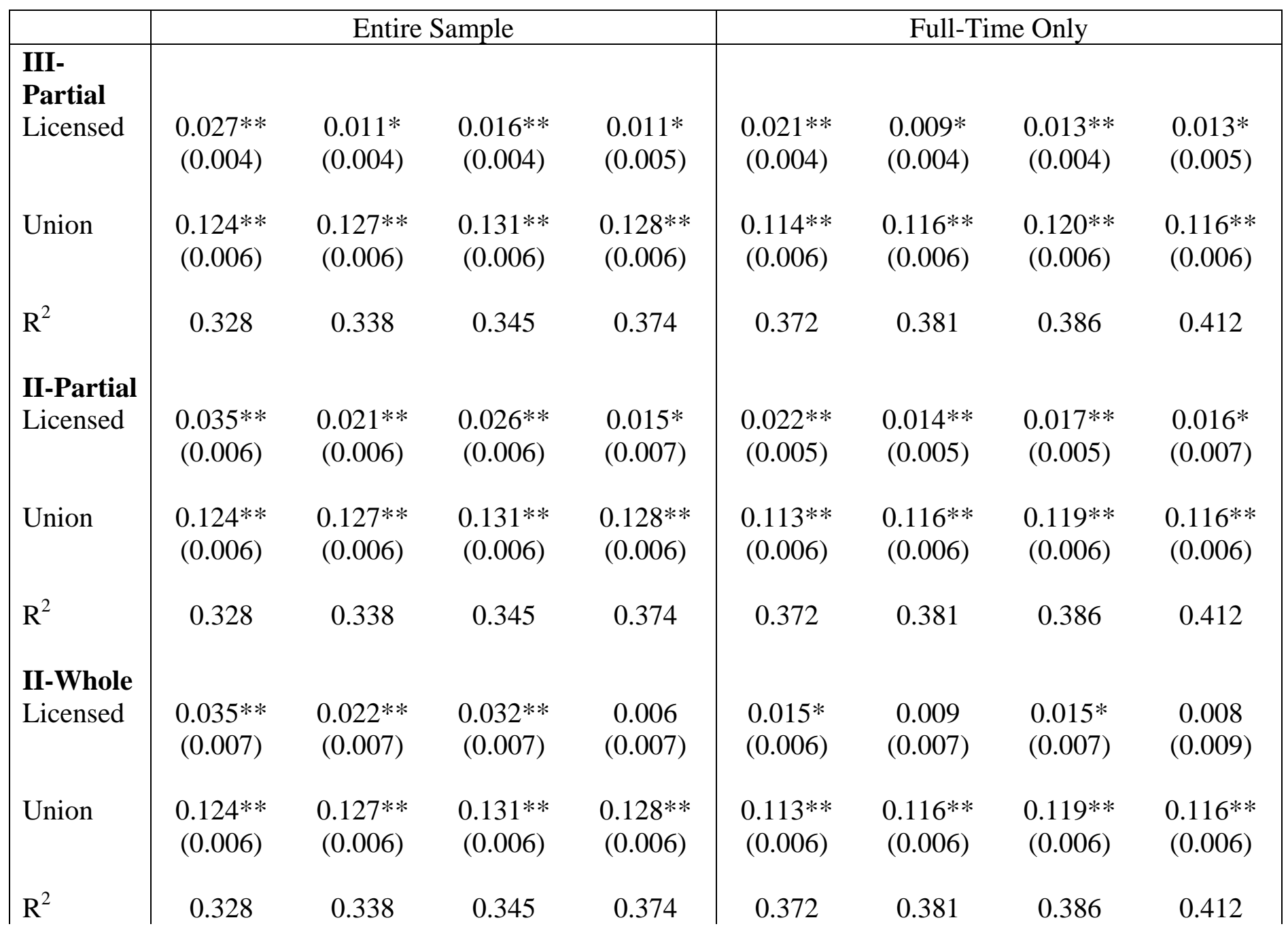




\begin{tabular}{|c|c|c|c|c|c|c|c|c|}
\hline $\begin{array}{l}\text { I-Partial } \\
\text { Licensed }\end{array}$ & $\begin{array}{c}0.044 * * \\
(0.008)\end{array}$ & $\begin{array}{c}0.030 * * \\
(0.008)\end{array}$ & $\begin{array}{c}0.041^{* *} \\
(0.008)\end{array}$ & $\begin{array}{c}0.002 \\
(0.010)\end{array}$ & $\begin{array}{c}0.020 * * \\
(0.008)\end{array}$ & $\begin{array}{l}0.013^{*} \\
(0.008)\end{array}$ & $\begin{array}{l}0.020^{*} \\
(0.008)\end{array}$ & $\begin{array}{c}0.004 \\
(0.011)\end{array}$ \\
\hline Union & $\begin{array}{c}0.124 \\
(0.006)\end{array}$ & $\begin{array}{c}0.127 * * \\
(0.006)\end{array}$ & $\begin{array}{c}0.131^{* *} \\
(0.006)\end{array}$ & $\begin{array}{c}0.128 * * \\
(0.006)\end{array}$ & $\begin{array}{c}0.113^{* *} \\
(0.006)\end{array}$ & $\begin{array}{c}0.116^{* *} \\
(0.006)\end{array}$ & $\begin{array}{c}0.119 * * \\
(0.006)\end{array}$ & $\begin{array}{c}0.116^{* *} \\
(0.006)\end{array}$ \\
\hline $\mathrm{R}^{2}$ & 0.328 & 0.338 & 0.345 & 0.374 & 0.372 & 0.381 & 0.386 & 0.412 \\
\hline \# Obs & 126,665 & 126,665 & 126,665 & 126,665 & 107,901 & 107,901 & 107,901 & 107,901 \\
\hline $\begin{array}{l}\text { Std. } \\
\text { Controls }\end{array}$ & Yes & Yes & Yes & Yes & Yes & Yes & Yes & Yes \\
\hline $\begin{array}{l}\text { Occ. } \\
\text { Controls }\end{array}$ & None & One-digit & Two-digit & Detailed & None & One-digit & Two-digit & Detailed \\
\hline
\end{tabular}

Notes: See text for licensing definitions and notes from Table 1 for sample criteria. Standard controls include human capital variables (controls for years of schooling, potential experience, and potential experience squared), indicators for union coverage, government employment, and self-employment, part-time status, and sets of dummy variables for major industry, state of residence, and year. There are 12 one-digit occupational categories under the 1970 codes and 10 under the 2000 codes, 44 two-digit categories under the 1970 codes and 22 under the 2000 codes, and 450 detailed categories under the 1970 codes and 454 under the 2000 codes.

Weighted by NLSY79 longitudinal weights.

Standard errors take account of complex survey design of NLSY79 and common group effects for detailed occupation by state cell (Moulton 1990; Cameron, Gelbach, and Miller 2011).

*Significant at 5 percent.

**Significant at 1 percent. 
Table 9

Impact of Licensing and Union Coverage on Wages 2002-2008 only

Licensing Definition: III-Whole

Cross-Sectional and Fixed-Effects Estimates

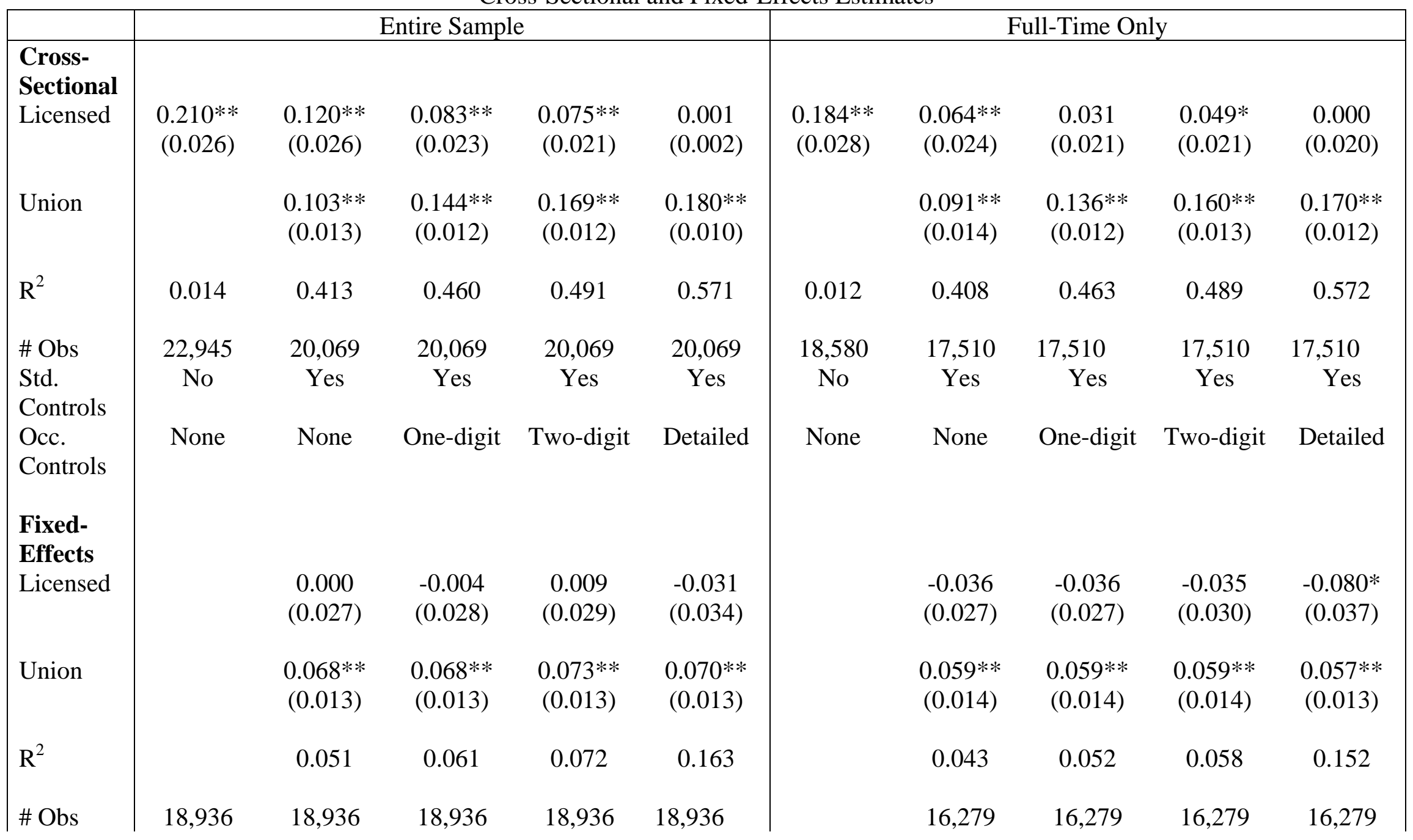




\begin{tabular}{|l|cccc|ccc}
$\begin{array}{l}\text { Std. } \\
\text { Controls }\end{array}$ & Yes & Yes & Yes & Yes & Yes & Yes & Yes \\
$\begin{array}{l}\text { Occ. } \\
\text { Controls }\end{array}$ & None & One-digit & Two-digit & Detailed & None & One-digit & Two-digit \\
\end{tabular}

Notes: See text for licensing definitions and notes from Table 1 for sample criteria. Standard controls for cross-sectional regressions include demographic and human capital variables (indicators for female, Hispanic and African-American, as well as controls for years of schooling, potential experience, and potential experience squared), indicators for union coverage, government employment, and self-employment, part-time status, and sets of dummy variables for major industry, state of residence, and year. There are 12 one-digit occupational categories under the 1970 codes and 10 under the 2000 codes, 44 two-digit categories under the 1970 codes and 22 under the 2000 codes, and 450 detailed categories under the 1970 codes and 454 under the 2000 codes.

Weighted by NLSY79 longitudinal weights.

Standard errors take account of complex survey design of NLSY79 and common group effects for detailed occupation by state cell (Moulton 1990; Cameron, Gelbach, and Miller 2011).

*Significant at 5 percent.

** Significant at 1 percent. 
Table 10

Impact of Licensing and Union Coverage on Access to Health and Retirement Benefits Licensing Definition: III-Whole

Linear Probability Models

\begin{tabular}{|c|c|c|c|c|c|c|c|c|c|c|}
\hline & \multicolumn{5}{|c|}{ Entire Sample } & \multicolumn{5}{|c|}{ Full-Time Only } \\
\hline Licensed & $\begin{array}{c}0.063 * * \\
(0.011)\end{array}$ & $\begin{array}{c}-0.011 \\
(0.008)\end{array}$ & $\begin{array}{c}-0.010 \\
(0.009)\end{array}$ & $\begin{array}{c}-0.008 \\
(0.010)\end{array}$ & $\begin{array}{c}-0.000 \\
(0.011)\end{array}$ & $\begin{array}{c}0.059 * * \\
(0.010)\end{array}$ & $\begin{array}{c}-0.018 * \\
(0.008)\end{array}$ & $\begin{array}{l}-0.014 \\
(0.009)\end{array}$ & $\begin{array}{l}-0.009 \\
(0.009)\end{array}$ & $\begin{array}{c}0.002 \\
(0.010)\end{array}$ \\
\hline Union & & $\begin{array}{c}0.115 * * \\
(0.006)\end{array}$ & $\begin{array}{c}0.126^{* *} \\
(0.006)\end{array}$ & $\begin{array}{c}0.125^{* *} \\
(0.006)\end{array}$ & $\begin{array}{c}0.122^{* *} \\
(0.006)\end{array}$ & & $\begin{array}{c}0.096 * * \\
(0.005)\end{array}$ & $\begin{array}{c}0.108 * * \\
(0.005)\end{array}$ & $\begin{array}{c}0.107 * * \\
(0.006)\end{array}$ & $\begin{array}{c}0.104^{* *} \\
(0.006)\end{array}$ \\
\hline $\mathrm{R}^{2}$ & 0.002 & 0.214 & 0.229 & 0.237 & 0.269 & 0.002 & 0.146 & 0.165 & 0.176 & 0.215 \\
\hline \# Obs & 114,840 & 108,553 & 108,553 & 108,553 & 108,553 & 100,752 & 97,502 & 97,502 & 97,502 & 97,502 \\
\hline $\begin{array}{l}\text { Std. } \\
\text { Controls }\end{array}$ & No & Yes & Yes & Yes & Yes & No & Yes & Yes & Yes & Yes \\
\hline $\begin{array}{l}\text { Occ. } \\
\text { Controls }\end{array}$ & None & None & One-digit & $\begin{array}{l}\text { Two- } \\
\text { digit }\end{array}$ & Detailed & None & None & One-digit & $\begin{array}{l}\text { Two- } \\
\text { digit }\end{array}$ & Detailed \\
\hline $\begin{array}{l}\text { Retirement } \\
\text { Licensed }\end{array}$ & $\begin{array}{c}0.101^{* *} \\
(0.014)\end{array}$ & $\begin{array}{l}-0.010 \\
(0.011)\end{array}$ & $\begin{array}{l}-0.018 \\
(0.011)\end{array}$ & $\begin{array}{l}-0.020 \\
(0.012)\end{array}$ & $\begin{array}{c}-0.004 \\
(0.014)\end{array}$ & $\begin{array}{c}0.095 * * \\
(0.013)\end{array}$ & $\begin{array}{c}-0.019 \\
(0.011)\end{array}$ & $\begin{array}{c}-0.024^{*} \\
(0.012)\end{array}$ & $\begin{array}{l}-0.023 \\
(0.012)\end{array}$ & $\begin{array}{l}-0.001 \\
(0.013)\end{array}$ \\
\hline Union & & $\begin{array}{c}0.170 * * \\
(0.009)\end{array}$ & $\begin{array}{c}0.184^{* *} \\
(0.009)\end{array}$ & $\begin{array}{c}0.185^{* *} \\
(0.009)\end{array}$ & $\begin{array}{c}0.183 * * \\
(0.009)\end{array}$ & & $\begin{array}{c}0.159 * * \\
(0.009)\end{array}$ & $\begin{array}{c}0.173 * * \\
(0.009)\end{array}$ & $\begin{array}{c}0.174 * * \\
(0.009)\end{array}$ & $\begin{array}{c}0.173 * * \\
(0.009)\end{array}$ \\
\hline $\mathrm{R}^{2}$ & 0.005 & 0.236 & 0.249 & 0.258 & 0.299 & 0.004 & 0.210 & 0.224 & 0.234 & 0.278 \\
\hline \# Obs & 76,034 & 71,112 & 71,112 & 71,112 & 71,112 & 66,607 & 64,415 & 64,415 & 64,415 & 64,415 \\
\hline $\begin{array}{l}\text { Std. } \\
\text { Controls }\end{array}$ & No & Yes & Yes & Yes & Yes & No & Yes & Yes & Yes & Yes \\
\hline
\end{tabular}




\begin{tabular}{|c|c|c|c|c|c|c|}
\hline \begin{tabular}{|l} 
Occ. \\
Controls
\end{tabular} & None & One-digit & $\begin{array}{l}\text { Two- } \quad \text { Detailed } \\
\text { digit }\end{array}$ & None & One-digit & $\begin{array}{l}\text { Two- } \\
\text { digit }\end{array}$ \\
\hline
\end{tabular}

Notes: See text for licensing definitions and notes from Table 1 for sample criteria. Standard controls include demographic and human capital variables (indicators for female, Hispanic and African-American, as well as controls for years of schooling, potential experience, and potential experience squared), indicators for union coverage, government employment, and self-employment, parttime status, and sets of dummy variables for major industry, state of residence, and year. There are 12 one-digit occupational categories under the 1970 codes and 10 under the 2000 codes, 44 two-digit categories under the 1970 codes and 22 under the 2000 codes, and 450 detailed categories under the 1970 codes and 454 under the 2000 codes.

Weighted by NLSY79 longitudinal weights.

Standard errors take account of complex survey design of NLSY79 and common group effects for detailed occupation by state cell (Moulton 1990; Cameron, Gelbach, and Miller 2011).

* Significant at 5 percent.

**Significant at 1 percent. 
Appendix A

Screenshot of CareerOneStop Website (http://www.acinet.org/licensedoccupations/)

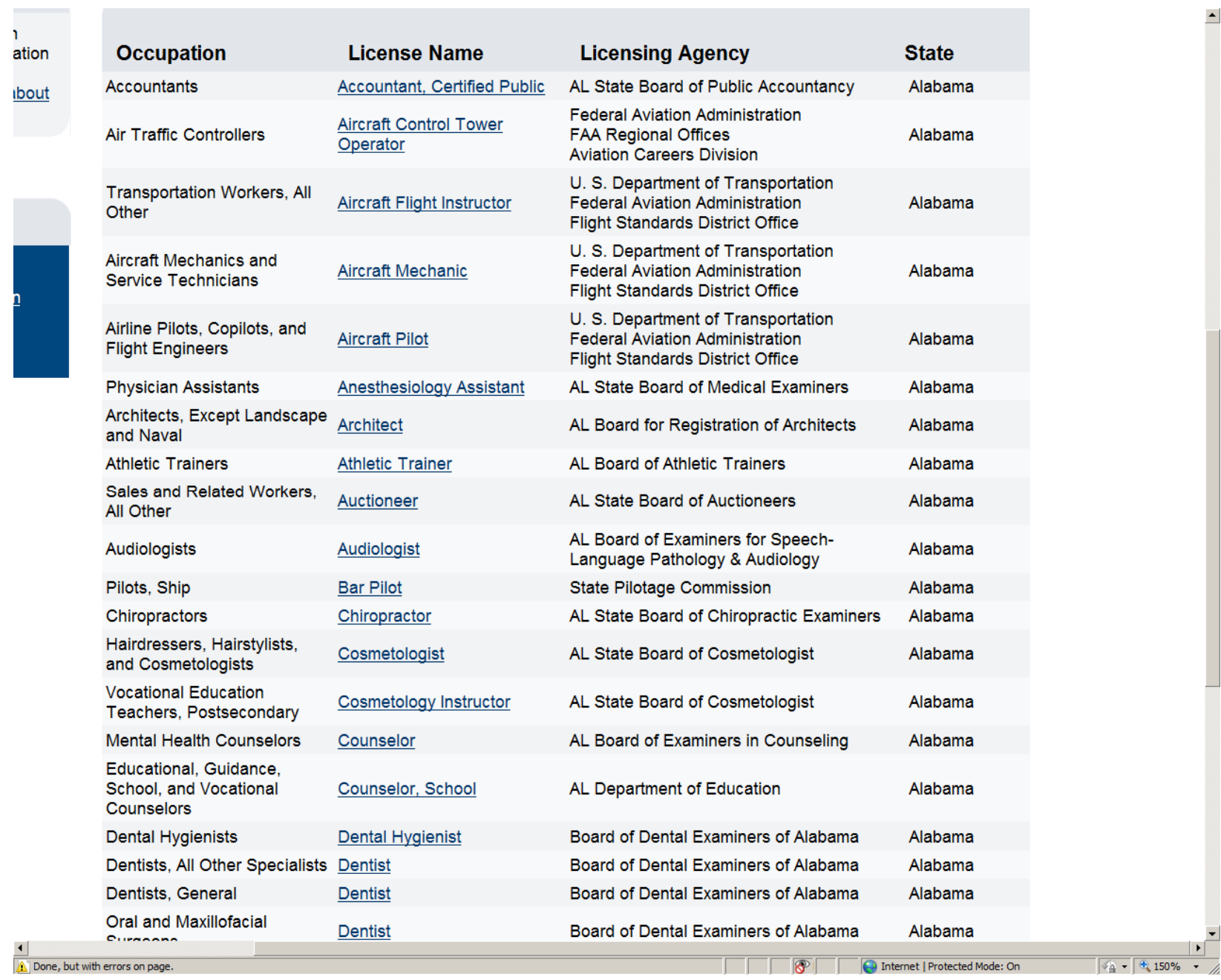


Appendix B

Number of Observations Associated with Changes in Licensing Status and Union Coverage in Table 5

\begin{tabular}{|l|c|c|c|}
\hline & Out of Licensed Job & Into Licensed Job & No Changes \\
\hline Licensing Moves & 7,498 & 7,421 & 66,249 \\
& 4,522 & 4,640 & 72,006 \\
& 3,105 & 3,053 & 75,010 \\
& 2,484 & 2,455 & 76,229 \\
& 2,370 & 2,288 & 76,510 \\
\hline
\end{tabular}

\begin{tabular}{|l|c|c|c|}
\hline Union Moves & Out of Union Job & Into Union Job & No Changes \\
\hline & 4,650 & 4,770 & 71,748 \\
\hline
\end{tabular}

\begin{tabular}{|c|c|c|c|c|c|c|c|}
\hline & $\begin{array}{l}\text { Out of } \\
\text { Licensed } \\
\text { and } \\
\text { Union } \\
\text { Job }\end{array}$ & $\begin{array}{l}\text { Out of } \\
\text { Licensed } \\
\text { Job, Union } \\
\text { Status } \\
\text { Unchanged }\end{array}$ & $\begin{array}{l}\text { Out of } \\
\text { Union Job, } \\
\text { Licensing } \\
\text { Status } \\
\text { Unchanged }\end{array}$ & $\begin{array}{l}\text { Into } \\
\text { Licensed } \\
\text { Job, Union } \\
\text { Status } \\
\text { Unchanged }\end{array}$ & $\begin{array}{l}\text { Into Union } \\
\text { Job, } \\
\text { Licensing } \\
\text { Status } \\
\text { Unchanged }\end{array}$ & $\begin{array}{l}\text { Into } \\
\text { Licensed } \\
\text { and } \\
\text { Union } \\
\text { Job }\end{array}$ & $\begin{array}{l}\text { No } \\
\text { Changes }\end{array}$ \\
\hline \multirow{5}{*}{ Both } & 451 & 6,559 & 3,699 & 6,458 & 3,819 & 463 & 58,731 \\
\hline & 311 & 3,900 & 3,992 & 3,980 & 4,146 & 313 & 63,868 \\
\hline & 215 & 2,693 & 4,229 & 2,639 & 4,365 & 208 & 66,416 \\
\hline & 158 & 2,183 & 4,332 & 2,134 & 4,466 & 161 & 67,431 \\
\hline & 163 & 2,068 & 4,343 & 1,986 & 4,473 & 158 & 67,694 \\
\hline
\end{tabular}

Notes: Total number of observation 81,168. See notes on Table 5. 
Appendix C: Estimates of the Impact of Occupational and Individual Licensing on Wage Determination

\begin{tabular}{|c|c|c|c|c|c|c|}
\hline VARIABLES & $\begin{array}{c}(1) \\
\text { lwage }\end{array}$ & $\begin{array}{c}(2) \\
\text { lwage }\end{array}$ & $\begin{array}{c}\text { (3) } \\
\text { lwage }\end{array}$ & $\begin{array}{c}\text { (4) } \\
\text { lwage }\end{array}$ & $\begin{array}{c}\text { (5) } \\
\text { lwage }\end{array}$ & $\begin{array}{c}(6) \\
\text { lwage }\end{array}$ \\
\hline Occupation Licensed & $\begin{array}{c}0.28 * * * \\
(0.03)\end{array}$ & $\begin{array}{c}0.16^{* * *} \\
(0.03)\end{array}$ & & & & \\
\hline Occupation Licensed \& Person Not Licensed & & & $\begin{array}{c}0.03 \\
(0.06)\end{array}$ & $\begin{array}{l}-0.02 \\
(0.06)\end{array}$ & & \\
\hline Occupation Licensed \& Person Licensed & & & & & $\begin{array}{c}0.30 * * * \\
(0.04)\end{array}$ & $\begin{array}{c}0.18^{* * * *} \\
(0.03)\end{array}$ \\
\hline Female & & $\begin{array}{c}-0.18^{* * *} \\
(0.03)\end{array}$ & & $\begin{array}{c}-0.18^{* * *} \\
(0.03)\end{array}$ & & $\begin{array}{c}-0.18 * * * \\
(0.03)\end{array}$ \\
\hline Asian & & $\begin{array}{c}0.08 \\
(0.10)\end{array}$ & & $\begin{array}{c}0.08 \\
(0.10)\end{array}$ & & $\begin{array}{c}0.09 \\
(0.10)\end{array}$ \\
\hline Hispanic & & $\begin{array}{l}-0.02 \\
(0.07)\end{array}$ & & $\begin{array}{l}-0.02 \\
(0.07)\end{array}$ & & $\begin{array}{l}-0.02 \\
(0.07)\end{array}$ \\
\hline Black & & $\begin{array}{l}-0.07 \\
(0.05)\end{array}$ & & $\begin{array}{l}-0.07 \\
(0.05)\end{array}$ & & $\begin{array}{l}-0.07 \\
(0.05)\end{array}$ \\
\hline Union & & $\begin{array}{c}0.19 * * * \\
(0.04)\end{array}$ & & $\begin{array}{c}0.21^{* * *} \\
(0.04)\end{array}$ & & $\begin{array}{c}0.19 * * * \\
(0.04)\end{array}$ \\
\hline Education & & $\begin{array}{c}0.07^{* * *} \\
(0.01)\end{array}$ & & $\begin{array}{c}0.07^{* * *} \\
(0.01)\end{array}$ & & $\begin{array}{c}0.06^{* * * *} \\
(0.01)\end{array}$ \\
\hline Government & & $\begin{array}{l}-0.03 \\
(0.04)\end{array}$ & & $\begin{array}{l}-0.03 \\
(0.04)\end{array}$ & & $\begin{array}{l}-0.04 \\
(0.04)\end{array}$ \\
\hline Service & & $\begin{array}{c}0.03 \\
(0.04)\end{array}$ & & $\begin{array}{c}0.04 \\
(0.04)\end{array}$ & & $\begin{array}{c}0.03 \\
(0.04)\end{array}$ \\
\hline Self Employed & & $\begin{array}{c}0.25 * * * \\
(0.08)\end{array}$ & & $\begin{array}{c}0.27 * * * \\
(0.08)\end{array}$ & & $\begin{array}{c}0.25^{* * *} \\
(0.08)\end{array}$ \\
\hline Northeast & & $\begin{array}{c}-0.10^{* *} \\
(0.04)\end{array}$ & & $\begin{array}{c}-0.10^{* *} \\
(0.04)\end{array}$ & & $\begin{array}{c}-0.10^{* *} \\
(0.04)\end{array}$ \\
\hline Midwest & & $\begin{array}{c}-0.12^{* * *} \\
(0.04)\end{array}$ & & $\begin{array}{c}-0.13^{* * *} \\
(0.04)\end{array}$ & & $\begin{array}{c}-0.12 * * * \\
(0.04)\end{array}$ \\
\hline South & & $\begin{array}{c}-0.09 * * \\
(0.04)\end{array}$ & & $\begin{array}{c}-0.09 * * \\
(0.04)\end{array}$ & & $\begin{array}{c}-0.08 * * \\
(0.04)\end{array}$ \\
\hline Age & & $\begin{array}{c}0.00 * * * \\
(0.00)\end{array}$ & & $\begin{array}{c}0.00 * * * \\
(0.00)\end{array}$ & & $\begin{array}{c}0.00 * * * \\
(0.00)\end{array}$ \\
\hline Work Experience & & $\begin{array}{c}0.01^{* * *} \\
(0.00)\end{array}$ & & $\begin{array}{c}0.01^{* * *} \\
(0.00)\end{array}$ & & $\begin{array}{c}0.01 * * * \\
(0.00)\end{array}$ \\
\hline Math & & $\begin{array}{l}0.02 * \\
(0.01)\end{array}$ & & $\begin{array}{c}0.02 * * \\
(0.01)\end{array}$ & & $\begin{array}{l}0.02 * \\
(0.01)\end{array}$ \\
\hline Read & & $\begin{array}{c}0.04 * * * \\
(0.01)\end{array}$ & & $\begin{array}{c}0.04 * * * \\
(0.01)\end{array}$ & & $\begin{array}{c}0.04^{* * *} \\
(0.01)\end{array}$ \\
\hline Observations & 1875 & 1875 & 1875 & 1875 & 1875 & 1875 \\
\hline R-squared & 0.30 & 0.43 & 0.28 & 0.42 & 0.30 & 0.43 \\
\hline Occ Controls & 2-digit & 2-digit & 2-digit & 2-digit & 2-digit & 2-digit \\
\hline
\end{tabular}

